\title{
La ultramodernidad de Leopoldo Marechal
}

\author{
Leopoldo Marechal's ultramodernity
}

\author{
CLAUDIA HAMMERSCHMIDT
}

Friedrich-Schiller-Universität Jena

Correo electrónico: claudia.hammerschmidt@uni-jena.de

\begin{abstract}
Resumen
Leopoldo Marechal (1900-1970), autor contemporáneo de Roberto Arlt y Jorge Luis Borges y de un peso literario comparable, fue silenciado largamente por la crítica argentina y nunca se reconoció en su debida dimensión como cofundador de la narrativa moderna argentina. Mi estudio parte de la base de que esta recepción difícil no solo se debe a causas ideológicas como su adherencia al catolicismo y peronismo desde los ańos 1930 y 1940, respectivamente, sino también a causas estéticas, y en concreto, a la 'ultramodernidad' de Marechal. Así, propongo analizar los modos paradojales, escenificaciones anacrónicas y mezclas ultramodernas de la escritura marechaliana como 'tercer paradigma' de la literatura argentina moderna. Después de un breve esbozo de la modernidad paradójica en general y la modernidad periférica en especial, analizo la ultramodernidad de su escritura, basándome en su primera novela Adán Buenosayres (1948) y su tendencia hacia el vaciamiento del presente. Hago hincapié en las (des)composiciones narrativas de la novela, sus superposiciones de voces, su "dialéctica en reposo" y sus diferentes poéticas en lucha. Termino mi análisis con una lectura de las figuras autoriales del texto como alegoría de la (de)posición, que desemboca en la alegoría (paródica) de la imitatio Christi. Esta, en su indeterminación entre signo y significado, su dimensión autodestructiva y la dialéctica entre lo premoderno y lo posmoderno, finalmente se cristaliza como alegoría de la escritura marechaliana: una escritura 'tachada' que se aniquila o sacrifica en el mismo momento de su realización, para así llegar a representar su propia imposibilidad y su paradoja ultramoderna.
\end{abstract}

Palabras clave: Leopoldo Marechal, Adán Buenosayres, literatura argentina moderna, ultramodernidad, escritura alegórica, alegoría.

Leopoldo Marechal (1900-1970), a contemporary author of Roberto Arlt y Jorge Luis Borges and of comparable literary weight, was silenced for a long time by Argentine critics and was never rightly acknowledged as cofounder of modern Argentine narrative. My research is based on the fact that this difficult reception is not only due to ideological causes, such as his adherence to Catholicism and Peronism from the 1930s and 1940s respectively, but also to aesthetic causes, and in particular to the 'ultramodernity' of Marechal. Thus, I propose to analyze the paradoxical modes, anachronistic staging and ultramodern blends of Marechal's writing as the 'third paradigm' of modern Argentine literature. 
After a brief sketch of paradoxical modernity in general and peripheral modernity in particular, I analyze the ultramodernity of his writing, based on his first novel Adán Buenosayres (1948) and his tendency towards the emptying of the present. I emphasize the narrative (de)compositions of the novel, its overlapping of voices, its "dialectics at a standstill" and its different struggling poetics. I conclude my analysis with a reading of the authorial figures of the text as an allegory of (de) position, which leads to the (parodic) allegory of the imitatio Christi. This, in its indeterminacy between sign and meaning, its self-destructive dimension and the dialectics between premodern and postmodern, finally crystallizes as allegory of Marechal's writing: a 'crossed-out' writing that annihilates or sacrifices itself at the same moment of its completion, in order to come to represent its own impossibility and its ultramodern paradox.

Keywords: Leopoldo Marechal, Adán Buenosayres, modern Argentine literature, ultramodernity, allegorical writing, allegory.

\section{A Abelardo Castillo, in memoriam.}

En su libro de ensayos Ser escritor, el importante dramaturgo, cuentista y novelista Abelardo Castillo, fundador y director de revistas literarias 'alternativas' de los años 60, 70 y 80 en Buenos Aires ${ }^{1}$ y gran conocedor de la vida literaria y cultural de su país, caracteriza la modernidad literaria argentina por la "Santísima Trinidad de la prosa nacional en el siglo XX”: Roberto Arlt - Jorge Luis Borges - Leopoldo Marechal (Castillo 2007: 177). Con esta afirmación no solo rinde homenaje al amigo, 'maestro' y autodenominado "poeta depuesto" $\mathrm{Marechal}^{2}$, sino que recupera a un autor eminente de la modernidad argentina que solo hasta tiempos relativamente recientes la crítica lo está tomando en consideración. A Arlt y a Borges, ya desde los años 1960 se les reconoce unánimemente como autores íconos de la narrativa moderna (o posmoderna) argentina y latinoamericana ${ }^{3}$. A Arlt, por la 'mala escritura' del hijo de inmigrantes en la metrópolis argentina (Saítta 2000; Carbone 2009), su "miserabilismo lumpen de la escritura" (Amícola 2014: 74), su "deseo de extranjería

${ }^{1}$ Cfr. El grillo de papel (1959-1960), El Escarabajo de Oro (1961-1974) o El Ornitorrinco (1977-1986). Ver al respecto Calabrese (2005/2006). Durante la redacción del presente artículo, el 2 de mayo de 2017 repentinamente falleció Abelardo Castillo. Exactamente un mes antes había empezado a establecer un largo diálogo sobre su relación con Marechal durante una entrevista que me brindó en su casa en Buenos Aires. En reconocimiento a su generosidad personal y a su obra insoslayable, quiero dedicarle este artículo sobre su maestro y amigo que fue Leopoldo Marechal.

${ }^{2}$ Así se había autodesignado Marechal después del derrocamiento de Perón en 1955 y el silenciamiento de su obra y persona por parte de la intelectualidad argentina antiperonista (cfr. Marechal 2008).

${ }^{3}$ Cfr. para una síntesis de la temprana recepción de Arlt p. ej. "Los lectores de Arlt: entre la censura y el reconocimiento" (Corral 1992: 13-17); para la recepción de Borges, p. ej. el temprano estudio de Ana María Barrenechea (1957). Como se sabe, a Borges no solo se considera ícono de la modernidad, sino, por su escritura rizomática, también de la posmodernidad; para esta lectura, cfr. sobre todo la nouvelle critique française de los ańos 1950 y 1960 (al respecto Rodríguez Monegal 1972). 
lingüística” y "realismo mesiánico" (Prieto 2016: 65 y 69); a Borges, por las "metáforas epistemológicas” (Alazraki 1976), la conjetura (Barrenechea 1957; Blanco 2015a), el simulacro (Yurkievich 1983) y "antipsicologismo" (Yurkievich 1996: 199), la "poética orilla" (Sarlo 1995: 38), o la "transversalidad" (de Toro 1999). En cambio, Leopoldo Marechal (1900-1970) $)^{4}$, el poeta, dramaturgo y sobre todo novelista de "novelas-epopeyas" (RoccoCuzzi 2004) como Adán Buenosayres ( $\left.{ }^{1} 1948\right)$, El Banquete de Severo Arcángelo $\left({ }^{1} 1965\right)$ o Megafón o la guerra ( $\left.{ }^{1} 1970\right)$, hasta hoy ha quedado fuera del canon argentino. Y a pesar de que su obra extensa y transgenérica, que marcó la escritura experimental del 'boom' y del neobarroco de novelistas como Cortázar, Lezama Lima, Cabrera Infante o Sarduy, se conozca y reconozca en Argentina desde la temprana crítica que le dedicara el joven Cortázar ya en $1949^{5}$, todavía hoy no se le reconoce en su debida dimensión de co-fundador de la narrativa moderna argentina y latinoamericana ${ }^{6}$.

\section{La posición IN-BETWEen, O EL 'TERCER PARAdigmA' de la MODERNidAd Argentina}

Esta recepción crítica difícil, lenta y atrasada no se debe exclusivamente a causas ideológicas como la adhesión al catolicismo y peronismo de Marechal desde los años 1930 y 1940, respectivamente ${ }^{7}$, sino también, como afirmaré en el presente estudio, a causas

\footnotetext{
${ }^{4}$ Para una visión de conjunto sobre aspectos bio-bibliográficos de Marechal, cfr. María de los Ángeles Marechal (2016).

${ }^{5}$ Cfr. el artículo que publica el 14 de marzo de 1949 en Realidad, bajo el pseudónimo de Julio Denis (Cortázar 1994). Al respecto, cfr. Navascués (1997) y Hammerschmidt (2016).

${ }^{6}$ Esto no implica, por supuesto, la inexistencia de una bibliografía crítica marechaliana, como lo demuestran, además de muchos estudios en forma de artículos, los trabajos monográficos que -desde perspectivas muy heterogéneas- ofrecieron Coulson (1974), Cavallari (1981), Cricco et al. (1985), Colla (1991), Navascués (1992a), Zubieta (1995), Maturo (1999), Cheadle (2000) y, más recientemente, Martínez Pérsico (2013) y Bravo Herrera (2015). Sin embargo, la crítica marechaliana aún hoy es relativamente escasa. Para una visión de conjunto de su recepción hasta 1974, cfr. "Contribución a la bibliografía de Leopoldo Marechal (en colaboración con William Hardy)" (Coulson 1974: 139-159); hasta 2000, cfr. "Problems in Marechalian criticism" (Cheadle 2000: 9-17); hasta 2015, cfr. "Sobre Leopoldo Marechal” (Bravo Herrera 2015: 396-413). Para una obra colectiva que presente los más recientes enfoques sobre Marechal, cfr. las actas del primer coloquio internacional sobre Marechal que realicé en 2013 en Jena, Alemania (Hammerschmidt 2015a).
}

${ }^{7}$ Con respecto a Marechal y el catolicismo, cfr. p. ej. Ramos (1979), Maturo (1999: 218-230) y María de los Ángeles Marechal (2016: 160); con respecto a Marechal y el peronismo, cfr. p. ej. Blanco (2015b), Hammerschmidt (2015c) y Navascués (2017: 188-208). Fue sobre todo su adhesión al peronismo la que causó el silenciamiento de Marechal, en parte ya durante el primer gobierno de Perón, cuando la mayoría de los intelectuales argentinos es abiertamiente antiperonista o 'gorila', como el famoso grupo reunido alrededor de Victoria Ocampo en Sur (1931-1970), revista que congrega muchos de los antiguos martinfierristas y excompañeros de Marechal (cfr. al respecto King 1986: 129-165). Más fuerte, sin embargo, para no decir total, es su silenciamiento a partir de la llamada 'Revolución libertadora' de 1955. Cfr. al respecto Navascués (2017: 75): "Tras el golpe de 1955, su nombre dejó de aparecer en la prensa y en las revistas culturales de todo signo. 
estéticas, y en concreto a la 'ultramodernidad' de Marechal. Ya que, a diferencia de Arlt y Borges -comparables entre sí en sus reescrituras de la literatura universal, pero confrontados en sus posturas antagónicas de, por un lado, una escritura más comprometida, anclada en la cultura popular o de 'las masas', y, del otro, el elitismo social y cultural de una vanguardia experimental y sofisticada ${ }^{8}-$, Marechal combina todas estas posturas en una escritura omnívora, paródica, alegórica, 'ultramoderna', que integra la reescritura constante de textos ajenos y propios, el intento de representar el nuevo sujeto social o la 'masa popular', la cita y burla del estilo épico y héroe clásico', y el escepticismo radical frente a las posibilidades miméticas del lenguaje. Así, sus largas novelas se transforman en mosaicos híbridos o frescos desfigurados que representan y al mismo tiempo descomponen la imagen que pretenden formar, impidiendo la configuración de una visión sólida y desarrollando, en cambio, una 'mirada estrábica' que siempre desdibuja y duplica lo visto. Sobre todo en su primera novela enciclopédica Adán Buenosayres ( $\left.{ }^{1} 1948\right)$, la heterogeneidad temático-ideológica y el multiperspectivismo de su escritura ocultan la posición desde la que se narra y le permiten a Marechal desarrollar una "estética de la indecisión" (Hammerschmidt 2015b: 272) que desconcierta toda epistemología, ontología o metafísica. Ya que la perspectiva polifónica desde la que se narra, lejos de limitarse a la mirada 'excéntrica' arltiana o a los simulacros intelectuales y conjeturales de Borges, se sitúa en la posición incómoda de un in-between. Es sobre todo su primera novela, escrita durante dos décadas y publicada cuando Marechal ya tenía 48 ańos, que presenta una summa de la cultura argentina, enfrentando a su protagonista -poeta 'adánico', idealista, (neo)platónico- con casi todas las capas sociales y discursos que luchan por la hegemonía y se contraponen en la capital argentina de los ańos veinte en que se ubica la novela ${ }^{10}$. Basado en la estructura clásica del viaje, aquí Adán -rumbo hacia su ideal, la belleza, poesía, o Solveig Amundsen- atraviesa y pasa revista a este potpurrí real, imaginario y ficticio que es la sociedad y su representación del momento: clase alta

Como el mismo afectado describió con melancólica ironía: su ejemplo era el del 'Poeta Depuesto', igual que el país, en el proceso de 'desperonización' que siguió a septiembre de 1955, había tenido su Gobernante Depuesto, su Militar Depuesto, su Abogado Depuesto, su Médico Depuesto, su Cura Depuesto, etc. [...]. Apenas publicó nada hasta 1965, año en el que su segunda novela, El banquete de Severo Arcángelo, obtiene el premio Forti Glori y su éxito lo saca del olvido". Fue recién a partir de 1965 que empezó a releerse a Marechal, y que también su Adán Buenosayres contó con una especie de renacimiento.

${ }^{8}$ Cfr. la famosa oposición de los dos grupos vanguardistas argentinos: el que se agrupaba en el barrio popular de Boedo y que, grosso modo, se caracterizaba por su compromiso social y su vanguardismo más bien político, a diferencia del grupo que se reunía en la elegante peatonal Florida, más caracterizado por su vanguardismo estético-intelectual y una posición política tradicionalista y europeizante (cfr. al respecto p. ej. Masiello 1986, Gilman 1989, Herrera Montero 1997, Baur/Bonet/Flores 2001, Carbone 2006 y 2009).

${ }^{9}$ En la secuela de Odiseo, Eneas, el caballero andante, el Criticón, o, ya más modernos, el pícaro, el "Meister" de Goethe y, muy evidentemente, el Ulysses de Joyce.

${ }^{10} \mathrm{Cfr}$. el análisis de Saítta, quien por la presencia de la masa obrera y la fuerte industrialización del país subraya la pertenencia de la Buenos Aires representada a los años cuarenta en vez de los veinte, como lo pretende el texto al ubicar la acción en un año indeterminado de 192... (Saítta 2004). 
porteña, europea y/o europeizante que celebra su feudalismo o aristocratismo en tertulias exclusivas; europeos imperialistas y materialistas que defienden sus sueńos de conquista capitalista con el positivismo y darwinismo social con que acompañan sus explotaciones del país; intelectuales despreocupados de la realidad que inventan mitos de una Argentina invisible, orillera, que se encuentra en obvia contradicción con la situación política y social que vive la sociedad; personajes populares del barrio, obreros, amas de casa o chicos que se amontonan en conventillos, bares o la calle para 'disputarse el día' y afirmarse en la lucha diaria por la vida y el reconocimiento social; pobres inmigrantes casi arltianos que sueñan con su pasado o futuro para olvidar la miseria, desilusión y angustia del presente; o finalmente individuos 'fuera de la ley', reproducciones del malevo martinfierrista de Borges, ubicados en los extramuros del arrabal y observados cual objeto de estudio por el grupo de intelectuales amigos de Adán - todos ellos parodiados en su anacronismo y puestos en escena como representantes de posturas ya caducas. Es casi como si Marechal hubiera propuesto una tercera posición o un puente entre las posiciones de Arlt y Borges para salir de la heterogeneidad dicotómica de la modernidad argentina y preparar una posibilidad de integración tanto social como cultural y estética de lo dispar, sin por esto propagar su armonización ${ }^{11}$.

El análisis que presento a continuación, basado en Adán Buenosayres, al concentrarse en esta vía heterodoxa y diferente a la propuesta por sus contemporáneos, intenta contribuir a hacer visible este 'otro lado' de la modernidad literaria constituida por Marechal y propone analizar sus modos paradójicos, escenificaciones anacrónicas y mezclas ultramodernas como 'tercer paradigma' o 'tercera posición'12 de la literatura argentina moderna. Procederé de

${ }^{11}$ Con esto difiero de la posición de Sebastián Hernaiz, quien, en la línea de Vińas (cfr. la siguiente nota), pretende que Marechal "narrará conflictos para armonizarlos", planteando "el ordenamiento como la postulación narrativa de una política” (Hernaiz 2007: 127 y 139). Si quizás el primer intento de Marechal había sido encontrar una vía de armonización de lo heterogéneo, como lo demuestra gran parte de su producción poética (cfr. el último verso de su soneto "Del amor navegante": "Con el número Dos nace la pena" [Marechal 2014: 232]), su producción novelística, polifónica, inclusiva, muy pronto da cuenta de la imposibilidad de tal pretensión. Quizás fue esta la causa fundamental del largo proceso escritural que, desde 1929 ("En París [1929], donde planeaba yo el Adán Buenosayres [...]"; Marechal 1966: 131) hasta 1948, atrasó tanto la publicación de su primera novela. Al dar cabida a la heterogeneidad cultural de la modernidad porteńa en su narrativa y exponer sus paradojas, Marechal tuvo que optar por una posición mucho más modesta (y moderna) que la de su supuesta 'armonización': incluir todo, dar constancia de todos los aspectos de la modernidad, social, urbana y estética, y dar voz a la "mazorca de hombres que se disputaban a gritos la posesión del día y de la tierra" (Marechal 2013: 97; íncipit). Sea mencionado de paso que esta apertura a lo heterogéneo y la exposición de sus conflictos parece haber sido también la razón para Marechal de elegir, a partir de los ańos 40 y a diferencia de Borges, el género de la novela para intentar representar estas 'paradojas de la modernidad'. Cfr. al respecto el análisis que sigue.

${ }^{12}$ Así, recurriendo al ensayo de David Viñas (1971), denomino la posición de Marechal entre Arlt y Borges en el proyecto de investigación DFG-CONICET-MinCyT "El 'paradigma Marechal' o la 'tercera posición' de la literatura argentina moderna". Cabe señalar que el brillante ensayo de Viñas hace hincapié en la "situación intersticial" (Viñas 1971: 104) de Marechal, cuya "obra se define centralmente entre su religiosidad y su populismo como tendencias ideológicas, por el predominio de lo simbólico o de lo cotidiano en sus textos 
la siguiente manera: después de un breve esbozo de la modernidad paradójica en general y la modernidad periférica en especial, analizaré la ultramodernidad de Adán Buenosayres basándome en su tendencia hacia la aniquilación y el vaciamiento del presente. Para esto, haré hincapié en las (des)composiciones narrativas de la novela, sus superposiciones de voces, su "dialéctica en reposo" y sus diferentes poéticas en lucha. Terminaré mi análisis con una lectura de las figuras autoriales de la novela como alegoría de la (de)posición, que desemboca en la alegoría (paródica) de la imitatio Christi. Esta, en su indeterminación entre signo y significado, su dimensión autodestructiva y la dialéctica entre lo premoderno y lo posmoderno, finalmente se cristaliza como alegoría de la escritura marechaliana: una escritura 'tachada' que se aniquila o sacrifica en el mismo momento de su realización, para así llegar a representar su propia imposibilidad y su paradoja ultramoderna.

\section{Paradojas de la modernidad}

Como bien se sabe, una de las características de la literatura moderna ${ }^{13}$ es la disolución en cuanto a su lenguaje, discurso y contenido. No solo se disuelven las reglas clásicas como el aptum entre forma y contenido o las estructuras cerradas de su presentación ${ }^{14}$, sino también las creencias en las posibilidades miméticas del lenguaje ${ }^{15}$, que se considera

teóricos y por el vaivén desde los 'vocablos excelsos' hacia las 'malas palabras’ en su lenguaje” (Viñas 1971: 104). Sin embargo, Viñas termina su análisis destacando el "esfuerzo de síntesis" (Viñas 1971: 107, 108), que no sería más que "la trasposición de la tertia via escolástica a la tercera posición del peronismo" de Marechal (Viñas 1971: 109). Con esto armoniza su propia lectura y convierte al autor de Adán Buenosayres en un místico con pretensiones políticas, "donde 'sin violencia' la cultura y las masas, América Latina y París, las novedades y lo tradicional, el lunfardo y lo clásico, nación y mundo, líder y pueblo se fundan” (Vińas 1971: 108). Con mi análisis, pretendo mostrar por el contrario que Marechal, al adoptar una escritura alegórica y ultramoderna de una 'tercera posición' que indica sus propias quiebras, se queda en el "intersticio" o el "estado de 'suspensión"” mencionados por Viñas (1971: 104), y resulta finalmente mucho más moderno, o ultramoderno, de lo que su recepción hasta hoy lo ha resaltado.

${ }^{13}$ Me refiero aquí a la literatura como empieza a concebirse fundamentalmente en Europa a partir de la segunda mitad del siglo XIX, es decir a la época que la crítica anglosajona denomina 'altomodernismo', y la crítica alemana, 'Hochmoderne'. Sin embargo, esta literatura se produjo casi simultáneamente en Europa y Latinoamérica, por su rápida recepción, propulsión, producción y transculturación en Latinoamérica por autores-nómades modernistas y cosmopolitas como Rubén Darío o, de otra índole, por la internacionalización efectuada por las vanguardias. Cfr. al respecto, entre otros, Ángel Rama (1970 y 1982), Rafael Gutiérrez-Girardot (1983) y Saúl Yurkiévich (1984).

${ }^{14}$ Cfr. para la ruptura de las formas, la apertura y la fragmentación de la obra moderna Eco (1962).

${ }^{15}$ Hay que señalar, sin embargo, este otro aspecto de la literatura moderna que son el realismo y naturalismo con sus pretensiones de un arte mimético más 'realista' que nunca, apto a no solo representar, sino cambiar, vía métodos científicos positivistas, las consecuencias del aburguesamiento, de la industrialización y de la pauperización de la capa social obrera a través de la novela. No obstante, hay que hacer hincapié en el hecho de que, además de hacer entrar a un nuevo sujeto social en el arte, los intentos de autentificación que en las novelas de Flaubert y Zola se 
incapaz de reflejar algo exterior o anterior a su propio acontecer ${ }^{16}$. Este mismo escepticismo frente a las posibilidades representativas y expresivas del lenguaje implica la desconfianza en la existencia de 'verdades', 'realidades' o 'esencias' ubicadas en un supuesto 'hors-texte' (Derrida 1967), y tanto las palabras como las cosas se experimentan en su extrema fragilidad, mendicidad y performatividad ${ }^{17}$. Así, entre las diversas facetas heterogéneas de la modernidad literaria, como lo son su creciente escepticismo, autonomía, contingencia, desauratización, temporalización, fragmentación o simulación ${ }^{18}$, prevalece su ambivalencia intrínseca, que a su vez indica su fuerte tendencia a dos grandes paradojas que la constituyen ${ }^{19}$.

Pues aparte de ilustrar el fracaso de la mímesis, la porosidad del mundo representado o la imposibilidad de encontrar un fin al texto ${ }^{20}$, la literatura moderna pone en escena al mismo tiempo su propia negación en una tendencia autodestructiva que le es inherente. Ya que gran parte de la literatura moderna se constituye por la lucha misma entre la descomposición de las ideas representadas, la escenificación de su imposible representación

producen p. ej. a través del detallismo desacelerante (cfr. el detalle supérfluo como productor de efectos de realidad de los que hablaba Barthes [1982]), ya demuestran la puesta en duda de la confianza en las capacidades miméticas del lenguaje. Cfr. al respecto el análisis que hace Peter Bürger en Prosa der Moderne: "Denn die Beglaubigung des Erzählten durch eine Realitätsillusion setzt voraus, daß das Erzählte einer solchen Beglaubigung bedarf. Das naive Vertrauen in das Erzählte, das die Märchenerzähler mit ihren Zuhörern verbindet, muß bereits in Frage gestellt sein im Namen eines Wahrheitsbegriffs, der Wahrheit mit Faktizität gleichsetzt [...]. Die illusionserzeugenden Techniken, die man mit dem Begriff des Realismus zusammenfaßt, sind also bereits eine Reaktionsbildung auf einen ersten Schub der gesellschaftlichen Modernisierung" (Bürger 1992: 385; "Pues la autentificación de lo narrado por una ilusión de realidad presupone que lo narrado necesita ser autentificado. La ingenua confianza en lo narrado, que une al contador de cuentos a su público, ya debe estar cuestionada en nombre de una noción de la verdad que iguala verdad con facticidad [...]. Las técnicas productoras de ilusión que se resumen bajo la noción de realismo entonces ya son una reacción a un primer tirón de la modernización social”; mi traducción, C.H.).

${ }^{16}$ Cfr., para la literatura europea, las luchas por la expresión y las búsquedas fracasadas de la palabra justa de un Mallarmé, Valéry, Rilke, Hofmannsthal, Joyce, o Döblin. Cfr. al respecto Kleinschmidt (1992).

${ }^{17}$ El fracaso de las llamadas "meta-narrativas", que se deduce de este reconocimiento constructivista de una verdad exterior al discurso, será llevado a su paroxismo después de la experiencia de la segunda guerra mundial, y sobre todo después de Auschwitz (cfr. Lyotard 1979).

${ }^{18}$ Cfr., entre otros, Benjamin (1991b [1936]), Blanchot (1949), de Man (1969), Deleuze (1969), Virilio (1980) y Rancière (2000).

${ }^{19}$ Con respecto a la modernidad paradójica, cfr. Compagnon 1990. Aunque Compagnon parte de "cinq paradoxes de la modernité", es decir: de la 'superstición de lo nuevo', la 'religión del futuro', la 'manía de la teoría', la 'apelación a la cultura' y la 'pasión del desmentido', por las razones que expondré a continuación, las reduzco a dos paradojas centrales: la tendencia a la autoaniquilación y al vaciamiento del presente.

${ }^{20}$ En su doble sentido de final o término y finalidad o meta. Es sobre todo la novela interminable o el romanfleuve de Marcel Proust, En busca del tiempo perdido (escrita entre 1906 y 1922, publicada entre 1913 y 1927), la que mejor escenifica el fracaso de la pretensión teleológica y la resultante infinitud del texto. Pues hace desembocar el final de la "recherche" (que a su vez es su fin, telos) al principio y así convierte tanto el texto como su proceso de lectura y su pretendida teleología en un movimiento cíclico, perpetuo, móvil y abierto. Cfr. al respecto mi análisis de Proust (Hammerschmidt 2010). 
y la constante proclamación o búsqueda de su reconstrucción por el texto mismo. Es como si buscara la misma superación de las bases que propone, en un irresistible afán de ir más allá de sí misma y de aniquilar la propia premisa de modernidad en la que se apoya ${ }^{21}$.

Esta inclinación hacia la construcción y autodestrucción simultánea, su tendencia a su negación o autofagocidad, puede considerarse la tendencia 'anti' o 'ultra' de la modernidad que le es inherente, y al mismo tiempo la paradoja central de la escritura moderna con la que debe enfrentarse. Fue Antoine Compagon quien dio en llamar "antimodernos" o "ultramodernos" a autores situados en el umbral o in-between entre épocas o discursos, que son modernos "à contrecœur", a su pesar, que se mueven entre el tradicionalismo y la vanguardia estéticos, y que ponen así en escena una de las paradojas centrales que constituye la modernidad literaria: su inclinación hacia la autodestrucción y la abolición de sus propios principios por la lucha entre conceptos filosófico-estéticos anacrónicos y su superación por la escritura misma (Compagnon 2016; para la introducción del término "ultramoderno", ver Compagnon 2016: 11). Retomo aquí su concepto de la 'ultramodernidad' como tendencia moderna a su propia superación y de la 'antimodernidad' como búsqueda de ciertos textos a restablecer el orden que anteriormente ellos mismos habían puesto en duda o destruido. Como se verá en el siguiente análisis, es especialmente en el contexto de las novelas de Marechal (donde se entrecruzan tendencias 'premodernas', 'modernas' y 'posmodernas') que este concepto ayuda a entender tanto la especificidad de este autor tantas veces ninguneado en los estudios sobre la modernidad literaria argentina, como también las razones de este silenciamiento.

Es esta misma ultramodernidad la que a su vez suscita la segunda de las grandes paradojas modernas: la tensión temporal tantas veces citada entre, por un lado, el deseo de lo nuevo o raro, de originalidad o excepcionalidad (cfr. Ortega 1998), y, por el otro, la nostalgia de algo -un tiempo, un lugar, un estado-siempre ya perdido en una anterioridad irrecuperable (cfr. Rössner 1988). Esta fragmentación de la sensibilidad moderna (tópica a más tardar desde Baudelaire), su división en una futuridad añorada y un pasado llorado, provoca a su vez la inaccesibilidad del presente -el momento y lugar desde el que se añoran o lloran tiempos y lugares lejanos-; un presente que en la modernidad constantemente se repliega sobre sí mismo para finalmente convertirse en elipsis ${ }^{22}$.

${ }^{21}$ Cfr. en este contexto también el movimiento vanguardista ultraísta, que sobre todo por la vuelta de Borges
a Buenos Aires tuvo mucha resonancia en Argentina en los años veinte. Ver al respecto p. ej. el manifiesto
borgeano (Borges 1921).
${ }^{22}$ Esta paradoja de la imposible presencia a sí, que marca inevitablemente la consciencia humana, puede resumirse
en el conocido neologismo creado por Jacques Derrida, différance, que hace referencia no a un posible estado de
diferencias, sino a la eterna e ineludible "production d'un système de différences" (Derrida 1972: 40): "[L]e a de
la différance rappelle aussi que l'espacement est temporisation, détour, délai par lequel l'intuition, la perception,
la consommation, en un mot le rapport au présent, la référence à une réalité présente, à un étant, sont toujours
différés" (Derrida 1972: 40). Esta différance, que según la filosofía deconstructivista marca el pensamiento y sus
representaciones desde siempre, se hace más palpable y manifiesta sobre todo en la modernidad por su agudo
trabajo sobre la relación entre las palabras y las cosas y los sistemas arbitrarios de la significación. Especialmente 
Una de las consecuencias de estas paradojas modernas es, como lo resaltó Walter Benjamin, la ausencia de una experiencia inmediata, imposibilitada en la modernidad por la intensidad del impacto de heterogéneas sensaciones o choques recibidos constantemente ${ }^{23}$ : es así que lo inmediato se suprime, sustrae y divide en una anterioridad y posterioridad inalcanzables, por lo que consecuentemente la consciencia moderna oscila entre, por un lado, la manía de la velocidad, transitoriedad y fugacidad de lo que así se evidencia contingente (cfr. Virilio 1980), y, por el otro, la adherencia a la tradición, la obsesión de la duración y la búsqueda de la eternidad, que se imaginan posibles en un tiempo-espacio otro que el momento vacío desde el que se habla ${ }^{24}$.

El arte moderno tiende así a su propia negación, y el presente (ausente) se convierte en huella fantasmagórica de la presencia perdida. Consiguientemente, es la reflexión de su propia temporalidad la que caracteriza al arte moderno; y es en la consciencia de su misma mortalidad que consiste su modernidad ${ }^{25}$.

\section{MODERNIDADES PERIFÉRICAS}

Según la crítica cultural Beatriz Sarlo, esta ambivalencia de la temporalidad o la paradoja de la ultramodernidad moderna se acentúan en lo que llama la "modernidad periférica” (Sarlo 1988). Si la simultaneidad de, por un lado, la celebración del futuro y la velocidad y, por el otro, la nostalgia de tiempos pasados y de la tradición, implica la paradoja, herida y heterogeneidad constitutivas de lo moderno, es en la llamada "modernidad

la escritura moderna, entonces, se vuelve "économie des traces" (Derrida 1972: 40) e implica su propio duelo (Kofman 1985).

${ }^{23}$ Benjamin, como se sabe, había afirmado que en la sociedad moderna, caracterizada por la alienación y el trauma, la literatura ya no transmite la experiencia, y la narración ya no se basa en la continuidad y sucesión, sino en la fragmentación y el choque. Por consiguiente, en sus ejemplos más avanzados, la literatura moderna forja un nuevo lenguaje basado en su propia arbitrariedad y desautomatización, que ya no pretende describir o representar, sino cambiar la realidad. Cfr. sobre todo Walter Benjamin, "Experiencia y pobreza" (Benjamin 1991e [11933]), "El narrador" (Benjamin 1991f [11936]), o "Sobre algunos temas en Baudelaire" (Benjamin 1991c [11939]). Sobre todo Florencia Garramuño ha claramente destacado que a pesar de estas afirmaciones, Benjamin siguió afirmando la función compensativa del arte y de la literatura, que sublima las pérdidas ocasionadas por la sociedad moderna y adopta una función mesiánica en preparación de un mundo nuevo (cfr. Garramuño 2009: 120-123).

${ }^{24}$ Son finalmente estas dos paradojas, la de la tendencia a la ultramodernidad y a la abolición del presente, y la de la tendencia simultánea hacia el futuro y el pasado, las que Baudelaire ya había destacado en 1863 en su famosa definición del pintor de la vida moderna: "La modernité, c'est le transitoire, le fugitif, le contingent, la moitié de l'art, dont l'autre moitié est l'éternel et l'immuable" (Baudelaire 1986: 372-373).

${ }^{25}$ Cfr. en este sentido la definición del arte moderno propuesta por Octavio Paz: "El arte moderno se sabe mortal y en eso consiste su modernidad” (Paz 1975, 113). Cfr., en otro contexto, también la estrecha relación entre cambio simbólico y muerte efectuada por el arte moderno según Baudrillard (1976), o los conceptos de trace o presencia sous rature elaborados por Derrida en su Grammatologie (1967). 
periférica" como la porteña de los años 20 y 30 que esta sustracción del presente y la copresencia de lo heterogéneo se exacerban en una "cultura de mezcla, donde coexisten elementos defensivos y residuales junto a los programas renovadores" (Sarlo 1988: 28) y donde todo está en lucha por la hegemonía. Hay que destacar en el contexto marechaliano que nos ocupa, que es en la lectura de los cuadros de Xul Solar (artista vanguardista, amigo de Marechal y modelo para el personaje Schultze, arquitecto infernal y guía del poeta en su infierno o último libro de Adán Buenosayres) que Sarlo resalta la técnica de la mezcla no solo de la "modernidad europea y diferencia rioplatense", sino también de dicotomías que, según Sarlo, caracterizan tanto a la sociedad argentina de los años 20 y 30 como a los cuadros enigmáticos del pintor vanguardista tan presente en la novela de Marechal: "Lo que Xul mezcla en sus cuadros también se mezcla en la cultura de los intelectuales: modernidad europea y diferencia rioplatense, aceleración y angustia, tradicionalismo y espíritu renovador; criollismo y vanguardia. Buenos Aires: el gran escenario latinoamericano de una cultura de mezcla" (Sarlo 1988: 15). Hay que matizar, sin embargo, que en su brillante análisis de los diferentes aspectos de esta 'modernidad periférica de mezcla', las heterogeneidades, simultaneidades disímiles o paradojas que describe Sarlo no se adscriben a un autor o una obra específicos ${ }^{26}$, sino que corresponden a una mirada de conjunto, que engloba las diferentes reacciones frente a los choques modernos y la diversidad de lo nuevo. Es así que Sarlo yuxtapone, entre otros, el 'criollismo gaucho' de Güiraldes (en Don Segundo Sombra, $\left.{ }^{1} 1926\right)$, que busca una 'edad dorada' perdida y se vuelve hacia un pasado rural, supuestamente armónico, anti-urbano; el 'criollismo urbano' de Borges, que desde Fervor de Buenos Aires $\left({ }^{1} 1923\right)$ se inserta en las orillas barriales para inventar mitológicamente Buenos Aires; la posición de Girondo, que ya en Veinte poemas para ser leidos en el tranvía ( $\left.{ }^{1} 1922\right)$ idolatra el presente del cual pretende poder apropiarse a través del erotismo de la mirada; la postura de Macedonio Fernández, que desde Papeles de Recienvenido ( $\left.{ }^{1} 1929\right)$ se repliega en la metrópolis desarrollando una estrategia narrativa de anti-physis y anti-representación; o la de Arlt, que a partir de El juguete rabioso ( $\left.{ }^{1} 1926\right)$ percibe la modernidad 'desde abajo', desde la perspectiva de los marginados, y destaca su lado angustiante y aniquilador. Sin embargo, es solo en Xul y -sin que Sarlo lo mencione ${ }^{27}$ - en Marechal que estas posiciones se cruzan en una suerte de 'pan-visión' o mezcla simultánea de rasgos modernos. Esta 'panvisión' se vuelve casi programática en Adán Buenosayres para entretejer lo supuestamente dicotómico e incluir, combinándolas, las diferentes tendencias (o niveles 'altos' y 'bajos') de la cultura moderna argentina, al mismo tiempo que ilustra su ultramodernidad inherente.

\footnotetext{
${ }^{26}$ Aparte de la de Xul, con la que Sarlo abre su libro.

${ }^{27}$ Sarlo solo lo menciona tres veces al pasar y lo excluye de su análisis.
} 


\section{La ultramodernidad de Adán Buenosayres, o El vaciamiento del presente}

Esta coexistencia de elementos heterogéneos, yuxtapuestos y entretejidos en una misma obra (que a la vez saluda lo nuevo, fugaz y acelerado, y llora un pasado siempre ya perdido, buscando la vuelta a una eternidad o un fuera-del-tiempo que se destruye en su misma búsqueda), convierte especialmente la narrativa de Leopoldo Marechal en uno de los ejemplos sobresalientes de la llamada "modernidad periférica" y hace entrar, condensándola, su heterogeneidad en el interior de un mismo texto. La presencia de escenarios e imaginarios realistas y a la vez tópicos de la historia cultural argentina, la confrontación de ámbitos dicotómicos, la puesta en escena de la pluralidad de voces ${ }^{28}$, la mezcla de estilos, escrituras y autores en citas y parodias constantes ${ }^{29}$, convierten sobre todo sus novelas en encarnaciones de esta "cultura de mezcla" que al mismo tiempo exhibe y condena la heterogeneidad de los elementos que la constituyen. Es en la narrativa de Marechal que, al confrontar la celebración y la condena de la multiplicidad de voces, perspectivas y verdades, esta mezcla escenifica su propia ultramodernidad e ilustra sus inevitables paradojas, inherentes tanto a la incompatibilidad de las varias voces que narran como también a la heterogeneidad de la realidad narrada.

Tal como se indica ya en su título, es especialmente en la primera novela de Marechal, Adán Buenosayres, donde se expone la paradójica coexistencia de la búsqueda de un paraíso perdido y añorado y la salutación de la vida polifacética, veloz y volátil de la metrópolis. Así, y esta es la hipótesis que planteo, en esta primera novela de Marechal se potencia la radicalidad de las paradojas modernas y se ponen en escena tanto la tendencia ultramoderna a la autoaniquilación como la différance de una experiencia inmediata y la consiguiente inaccesibilidad del presente. Al mismo tiempo, Adán Buenosayres saca la conclusión de esta situación paradójica al proponer el sacrificio (autorial, escritural, referencial, pero también

\footnotetext{
${ }^{28}$ Cfr. p. ej. la siguiente cita, que se encuentra en las páginas iniciales de Adán Buenosayres: "Irma gritaba los versos iniciales de 'El Pańuelito'. Calló de pronto [...]: sus oídos atentos captaron en un solo acorde la canción de los albañiles italianos, el martilleo del garaje 'La Joven Cataluña', el cacarear de las gordas mujeres que discutían con el verdulero Alí, la oferta grandilocuente de los judíos vendedores de frazadas y el clamor de los chiquilines que se hacían polvo detrás de una pelota de trapo" (Marechal 2013: 98).

${ }^{29}$ Estas, como en la definición clásica de la parodia, muchas veces funcionan a través de las constantes diferencias entre el nivel temático en el que se mueve el protagonista y el nivel estilístico en el que el narrador lo presenta. Daré solo un ejemplo, otra vez del primer libro de Adán Buenosayres: "iNúmenes de Villa Crespo, duros y alegres conciudadanos; viejas arpías gesticulantes como gárgolas, porque sí o porque no; malevos gruñidores de tangos o silbadores de rancheras; demonios infantiles, embanderados con los colores de River Plate o de Boca Juniors; carreros belicosos que se agitaban en lo alto de sus pescantes y se revolvían en sus cojinillos, para canturrear al norte, maldecir al sur, piropear al este y amenazar al oeste! ¡Y sobre todo vosotras, muchachas de mi barrio, dúo de taconeos y risas, musas del arrabal con la tos o sin la tos de Carriego el poeta! Bien sé yo que si trepando la escalera del número 303 se hubiesen asomado todos ellos a la habitación de Adán Buenosayres, la presencia del héroe dormido les habría inspirado un generoso silencio" (Marechal 2013: 100).
} 
cultural ${ }^{30}$ y social $\left.{ }^{31}\right)$ como única solución a este estado paradójico. Al proyectar las paradojas de la modernidad desde un presente narrado que a su vez está dividido entre las tensiones temporales (velocidad o tensión hacia el futuro ${ }^{32}$ y nostalgia o ańoranza de un pasado perdido ${ }^{33}$ ), Marechal intensifica y potencia su efecto al marcar su hiato y tachar incluso la posición desde la que se habla ${ }^{34}$. Así, las tendencias contrarias se duplican en una condensación poética que intensifica la constante lucha y tensión expuestas. Entre el primer hombre de la Biblia, Adán nomoteta que crea nombrando, y la capital contemporánea babilónica que se le enfrenta, se abre el mismo abismo que entre el personaje central que lleva el nombre dicotómico y su narrador que pretende presentarlo. De esta manera se imposibilita toda posición; y entre las diversas actitudes -la búsqueda de la uni(voci)dad y la afirmación de la mezcla- siempre se interpone un hueco que suspende todo sentido y ubicación espaciotemporal en una autoaniquilación que va más allá de su propia posición moderna.

Se podría decir entonces que la novela saca las consecuencias de su modernidad paradójica, periférica y 'ultramoderna'; ya que si por un lado incorpora los aspectos multifacéticos y contradictorios de la modernidad argentina de los años veinte ${ }^{35}$, por el otro se sabe mortal y dividida entre los tiempos, espacios y perspectivas desde las que se presenta, sin nunca poder encontrar su punto de anclaje o presencia inmediata. Pues a pesar de que el texto hable constantemente del tiempo y lugar de la acción, ponga en escena personajes y situaciones de las calles capitalinas y reflexione sobre sus propias estrategias poéticas, la novela se mueve en una zona indecisa donde las coordenadas pierden estabilidad y todo se vuelve ambivalente, incierto, 'sin atributos' (Musil 1978). Las mismas técnicas narrativas

${ }^{30} \mathrm{Cfr}$. con respecto al sacrificio cultural a través de la parodia mis notas 38 y 39 .

${ }^{31} \mathrm{Cfr}$. con respecto al sacrificio social las parodias de la sociedad porteńa sobre todo en los libros II, III y VII de Adán Buenosayres (cfr. también mi nota 42), y especialmente también en la última novela de Marechal, Megafón o la guerra ( $\left.{ }^{1} 1970\right)$. Este aspecto lo estoy estudiando para un trabajo monográfico sobre la recepción de Marechal en la literatura argentina a partir de los ańos 60, de próxima aparición.

${ }^{32}$ Cfr. p. ej. las escenas callejeras que se montan en la flânerie de Adán por Villa Crespo, las largas discusiones camaleónicas del grupo amigo de Adán al atraversar el arrabal, o el apellido mismo del protagonista, Buenosayres, que resume la vida moderna urbana.

${ }^{33}$ Cfr. p. ej. los recuerdos de la infancia adánica en Maipú, la poética (neo)platónica defendida en el simposio de la glorieta de Ciro Rossini, el "Cuaderno de Tapas Azules" (Libro VI) o el mismo nombre de Adán, que resume sus aspiraciones paradisíacas e imposibles.

${ }^{34}$ En Adán Buenosayres, por un lado no se conoce el tiempo desde el que se narra -ni el prólogo ni los siete libros se sitúan en un tiempo concreto, el último libro se narra desde un "ahora" no definible (cfr. Macciuci 2015: 443, nota 6), y entre el último libro y el prólogo se abre un hiato indeterminado (cfr. Navascués 1992a: 101, 125, y 261-261; Cheadle 2000: 24)-; y por el otro se multiplican las voces narradoras, imposibilitando así saber desde qué perspectiva o posición se habla: si el texto se narra desde la nostalgia adánica de una unidad perdida y una añoranza del pasado, o desde la afirmación vanguardista de la heterogeneidad y la orientación hacia el futuro. Cfr. el análisis temporal y narratológico del próximo subcapítulo.

${ }^{35} \mathrm{O}$ de los años cuarenta, como lo sugiere la presencia de (o alusión a) las masas obreras que corresponde sobre todo a la época peronista (cfr. otra vez Saítta 2004). 
y retóricas empleadas en Adán Buenosayres corroboran la indecidibilidad y socavan, en el propio acto de su construcción, las realidades o posiciones que se ponen en escena. De alguna manera, por su misma heterogeneidad dinamitan y multiplican la escritura, y la novela se convierte en un dominio de la lucha donde se negocian capitales simbólicos y estrategias de simbolización sin que ninguno salga ganando. Entre los siete libros de la novela se entrecruzan estéticas divergentes, se mezclan mecanismos narrativos opositivos y se yuxtaponen figuras retóricas premodernas, modernas y posmodernas que entran en batalla sin que ninguna logre imponerse completamente. Parece como si el texto expusiera la lucha de las posiciones ideológicas y estéticas, que no se vencen, pero tampoco se rinden. Es esta "estética de la indecisión" (Hammerschmidt 2015b: 272) entre posiciones sólidamente afirmadas la que distingue la ultramodernidad de la estética marechaliana de p. ej. la modernidad de un Arlt o la posmodernidad de un Borges. En lo que sigue, quiero por ende concentrar mi análisis en esta indecidibilidad de Adán Buenosayres, partiendo tanto de una somera lectura narratológica como de la "nueva retórica" o "retórica de la temporalidad" en el sentido que le ha otorgado Paul de Man (1969 y 1991). Así, leeré la primera novela de Marechal como campo de batalla entre concepciones ideológicas y estéticas opuestas, donde por un lado se parte de la representación como coincidencia entre res y verba (y consiguientemente de la continuidad y congruencia simbólica entre representación y objeto representado ${ }^{36}$ ), y por el otro de la concepción paródica de la representación (que subraya su propia imposibilidad y siempre señala la distancia entre representación y mundo representado). De esta manera, según mi punto de vista, la escritura de Marechal expone su ultramodernidad estética en la simultánea amplificación y disolución de las dicotomías expuestas, que finalmente, con el descenso al infierno y la muerte de Adán (pero también por su paródica confrontación con un perro), desembocan en el gran vacío de un presente (o una presencia) ausente. Consecuentemente, el texto se convierte en alegoría que expone su hiato, la intermitencia, la imposibilidad de una síntesis, que paradójicamente siempre se busca sin que se encuentre nunca $^{37}$. Así, esta alegoría significa a la vez el trabajo de duelo como también una forma de resistencia a los efectos de la modernidad, sea esta 'clásica', periférica, o ultramoderna.

\section{5. (Des)COMPOSICIONES NARRATIVAS}

Adán Buenosayres desde su publicación en el año 1948 fue considerado un verdadero monstruo: no sólo por su extensión que, según las ediciones utilizadas, varía entre 562 (en Archivos: cfr. Marechal 1997), 644 (en Sudamericana: cfr. Marechal 1984), 748 (en Corregidor: cfr. Marechal 2013) y 835 páginas (en Clásicos Castalia: cfr. Marechal 1994), sino

\footnotetext{
${ }^{36}$ Donde idealiter el objeto representado se diluye en la representación (y viceversa), por lo que finalmente la representación se neutraliza y se funde con el objeto representado.

${ }^{37}$ Otra vez quiero oponerme explícitamente a la lectura de Marechal como autor de una síntesis ingenua, como la propone Hernaiz (2007) en la línea de Viñas (1971). Remito aquí a mis notas 11 y 12.
} 
y sobre todo por su estructura heterogénea. Esta heterogeneidad estructural, íntimamente ligada a una dualidad de voces, resulta sobre todo del cambio (ficticio) de autoría y de concepto escriturario que se efectúa en la novela: a un "Prólogo indispensable" firmado por L. M. y cinco libros de su misma autoría que pretenden constituir "una semblanza de Adán Buenosayres [...] en función de vida”, siguen los libros VI y VII, supuestamente escritos por el protagonista de los libros I a V, Adán, muerto ya en el "Prólogo". Mientras que los libros de L. M. corresponden a un narrador omnisciente, pero altamente paródico, que se burla no sólo de sus propios personajes, sino de la cultura argentina en general, de sus mitos fundadores $^{38}$ y mitificaciones poéticas ${ }^{39}$, sus escenas barriales ${ }^{40}$ o tertulias intelectuales ${ }^{41}$, los

${ }^{38}$ En especial de la búsqueda por un mito fundador, como la constituyen la glorificación del gaucho y la
transformación del Martín Fierro en epopeya nacional por autores del primer Centenario como Leopoldo
Lugones (en su Payador, ${ }^{1} 1913 / 1916$ ), la resurrección de un 'espíritu de la tierra' romántico por Raúl Scalabrini
Ortiz (en El hombre que está sólo y espera, ${ }^{1} 1931$ ), o la mitología arrabalera del martinfierrismo de los ańos 1920 .
- Para el tema de la burla a los tópicos de la nación, cfr. sobre todo Ana María Zubieta, que habla de la "galería
de la cultura nacional" establecida por el Adán Buenosayres (Zubieta 1995: 99-148; también Hammerschmidt
2004 y 2015 b: 274-275). Muy significativa, por supuesto, es la famosa travesía de Saavedra de Adán y sus
amigos en una “[a]ventura criolli-malevi-fúnebri-putani-arrabalera" (Marechal 2013: 236), donde el grupo de
'aventureros' debe enfrentarse a las personificaciones paródicas de la historia cultural argentina: el Gliptodonte
o Espíritu de la Tierra (cfr. Marechal 2013: 272-276) -parodias de las teorías de Ameghino y Scalabrini Ortiz-;
el Cacique Paleocurá (cfr. Marechal 2013: 279-281) -parodia de los indios ranqueles de Lucio V. Mansilla-; el
Santos Vega (cfr. Marechal 2013: 282-284) y Juan sin Ropa (cfr. Marechal 2013: 284-286) de Hilario Ascasubi y
Rafael Obligado; o el Cocoliche (cfr. Marechal 2013: 286) del sainete criollo; personificaciones paródicas que se
desplazan hasta llegar al Neocriollo (cfr. Marechal 2013: 288-289) de Xul Solar, que a su vez, tras haber soltado
un pedo luminoso, también termina por desvanecerse en la negrura. En otro contexto, constaté al respecto:
"Todas estas encarnaciones son efímeras, se sustituyen mutuamente y llevan a su muerte sucesiva, como lo señala
ya el mismo taita e ídolo martinfierrista, el muerto Juan Robles, que es causa y meta de la excursión y objeto
venerado del velorio suburbano [al que se dirige el grupo de amigos]" (Hammerschmidt 2015b: 275).

${ }^{39}$ Como lo son sobre todo el taita o malevo, inventados por el tango y el martinfierrismo. - Para la pertenencia de Marechal al mismo martinfierrismo del que veinte años más tarde se burlará en el Adán Buenosayres (sobre todo en la versión del personaje Luis Pereda alias Jorge Luis Borges), cfr. p. ej. Navascués (1992b), Lojo (1987), y Zonana (1991). Para un análisis de la refuncionalización de su propia poesía martinfierrista en su novela, cfr. Romano (1997).

${ }^{40}$ Como p. ej. la pelea o 'guerra épica' que se arma entre dos chicos de Villa Crespo y sus respectivas madres (Libro II, 1), de la que cito solo un corto fragmento: "Cuando Adán Buenosayres llegó a 'La Buena Fortuna', el combate se iniciaba ya. Dentro de un vasto círculo de hombres y mujeres, dońa Filomena, erguida en toda la majestuosidad de su estatura, rojos los cachetes como la cresta de un gallo y sin soltar los tiradores de Yuyito que forcejeaba por evadirse de aquel rigor materno, dirigía la ferocidad de sus ojos contra un duro enemigo. Frente a ella, y pálida como el ángel de la muerte, dońa Gertrudis resistía el fulgor de aquellos ojos, apretando contra su vientre la cabeza de Juancho. Puesto entre ambas campeonas el tano Luigi, propietario de 'La Buena Fortuna', miraba el roto cristal de su vidriera y prorrumpía en grandiosas lamentaciones. Un cerco de rostros amenazantes limitaba la palestra; y la multitud acudía desde los cuatro puntos cardinales del Globo" (Marechal 2013: 191).

${ }^{41}$ Como p. ej. la tertulia kitsch en la casa o 'corte' de los Amundsen (Libro II, 2), adonde llega Adán después de haber pasado por las peligrosas calles porteñas para entregarle su "Cuaderno de Tapas Azules" a Solveig: "Con una espléndida manotada en los registros bajos Ethel Amundsen dio fin a la rapsodia: se tambaleó el 
libros VI y VII difieren completamente del texto de L. M. e incluso discrepan entre ellos. El libro VI, o "Cuaderno de Tapas Azules", forma la 'autobiografía del alma' del poeta Adán Buenosayres, pertenece mayoritariamente a la filosofía (neo)platónica y se destaca por su estilo solemne y su poética idealista, mientras que el libro VII, o "Viaje a la Oscura Ciudad de Cacodelphia”, es la descripción autodiegética del viaje de Adán y de su amigo Schultze al infierno de la capital argentina ${ }^{42}$ del cual ninguno de los dos volverá. Si entonces el discurso de Adán refleja una estética culta y elitista que, o se encierra tal un nuevo Narciso en su propio reflejo al presentar su dilema amatorio y escriturario, o condena a los tipos populares de su entorno al infierno de Cacodelphia, L. M. incorpora lo popular a sus libros, en los que se presentan escenas callejeras donde las vecinas gordas del barrio se entrecruzan con vendedores ambulantes, las 'mujeres caídas' del tango como Flor de Barrio con hinchas de fútbol, y los cocheros bolicheros con inmigrantes italianos que añoran su patria dejada atrás.

Desde el inicio de la novela se sabe entonces que en Adán Buenosayres no habla un único narrador, sino que se superponen dos voces narrativas heterogéneas donde la segunda parece depender de la primera: por un lado, la voz narrativa de L. M., que firma el "Prólogo indispensable" donde se explica la necesidad de introducir al poeta Adán Buenosayres biográficamente -introducción que se dará en los libros I a V, también narrados por L. M. en tercera persona-; y, por otro lado, la voz narrativa de Adán Buenosayres, poeta, cuyos libros VI y VII se presentan autodiegéticamente en la primera persona de Adán. Estas autobiografías del poeta parecen depender entonces del supuesto relato marco de L. M.;

piano vertical, oscilaron y cayeron los dos pastores de terracota que yacían sobre la tapa del instrumento; y el bergantín anclado entre los dos pastores cabeceó de súbito, como si acabase de soltar amarras. Aplausos calurosos resonaron en el salón, y subieron de punto cuando Ethel Amundsen, dando una media vuelta en el taburete giratorio, se puso de pie y caminó hacia el diván celeste meneando sus firmes caderas de guitarra [...]. [Paralelamente y mientras tanto:] Significativo era el gesto con que la señora Amundsen acababa de subrayar su confidencia.

-¿¿Duro? -le preguntó en voz baja la señora de Ruiz.

-Como una piedra. Y eso cada ocho días. Y gracias a un laxante preparado con aceite de ricino, belladona y beleño, que debía tomar en ayunas por la mañana.

La señora de Ruiz consideró esos detalles con la indulgencia del veterano que oye contar a un novicio su primer hecho de armas. A su vez la señora de Johansen lo escuchaba todo con visible tristeza; y recuerdos amargos debían de acudir a su memoria, pues dos arrugas atravesaban su frente y el mentón reflexivo se le hundía en la doble papada" (Marechal 2013: 198 y 219).

${ }^{42}$ Infierno que por un lado duplica al infierno dantesco, pero que por el otro brinda la ocasión a una crítica social por el reencuentro de Adán con muchos personajes de los libros anteriores que aquí, en el infierno, relatan y discuten sus variados y, a veces, divertidos pecados. Para un análisis del Libro VII, ver p. ej. Barcia (1994: 7492) y Cheadle (2000: 84-121). Para la relación del Libro VII con el Inferno de Dante, cfr. Grossmann (1972). Para un análisis político de Cacodelphia, cfr. Rocco-Cuzzi (2004). Aquí, Rocco-Cuzzi afirma que el "recorrido del infierno en Adán Buenosayres funciona como un catálogo de aquellos sujetos que desvían al pueblo de su destino: los irresponsables, los políticos corruptos, los intelectuales, los hipocondríacos, etcétera. Lo contrario de Cacodelphia será un lugar donde cada uno ocupe el sitio que le corresponde para garantizar que los integrantes del Demos elijan el camino del bien. Por la vía de la crítica de la vida real, la novela diseña su utopía de una comunidad regida por otros valores" (Rocco-Cuzzi 2004: 465). 
porque Adán, como bien lo narra L. M. en su prólogo, se entierra alegremente ya al inicio antes de que empiece la narración 'propiamente dicha ${ }^{43}$. Es por ende la muerte de Adán que hace decidirse al amigo y 'editor' L. M. a publicar el libro sobre la poética (VI) y el descenso al infierno (VII) del poeta, recurriendo así a la clásica ficción de editor en un prólogo que se sitúa tanto fuera como dentro de la historia narrada

Pero las apariencias engañan. Lo que por el sutil manejo del prólogo parece iniciarse como la dependencia clásica de un personaje (Adán) de su narrador o autor (L. M. obviamente un narrador con las iniciales de su autor, Leopoldo Marechal), por la estructura de los siete libros resulta ser todo lo contrario. Ya que lo que se pone en escena es el diálogo entre las voces y sus diversas estéticas, en donde ninguna lleva la voz cantante ${ }^{44}$. Es, casi como en una ilustración del dialogismo y la carnavalización literaria como los propuso Bajtín (cfr. Bakhtine 1970 y 1978) para la novela, la co-presencia de lo heterogéneo, la mezcla sin jerarquía, la indecisión entre posturas la que se escenifican entre diálogo; y no solo la indecisión entre conceptos, tiempos o culturas, sino también entre imágenes de dos autores que se confrontan sin que ninguno salga ganando, como lo demuestra ya un breve análisis narratológico que se basa en la reconstrucción de la cronología caotizada de la novela y que presento a continuación.

Ya Graciela Coulson (1974) había destacado que, desde el punto de vista cronológico, la novela de Marechal comienza con las primeras doce secciones del Libro VI o "Cuaderno de Tapas Azules", que son la autobiografía del alma de Adán hasta su decisión de entregarle el cuaderno a su amada Solveig Amundsen. A esta primera parte del "Cuaderno" le siguen los Libros I a IV, es decir la descripción del despertar de Adán un 28 de abril de

\footnotetext{
${ }^{43}$ Con respecto al prólogo como paratexto, que se sitúa en el umbral del texto, cfr. Gérard Genette: "Le paratexte est donc pour nous ce par quoi un texte se fait livre et se propose comme tel à ses lecteurs [...]. Cette frange [...], toujours porteuse d'un commentaire auctorial, ou plus ou moins légitimé [sic] par l'auteur, constitue, entre texte et hors-texte, une zone non seulement de transition, mais de transaction: lieu privilégié d'une pragmatique et d'une stratégie, d'une action sur le public au service [...] d'un meilleur accueil au texte et d'une lecture plus pertinente [...] aux yeux de l'auteur" (Genette 1987: 7-8).

${ }^{44}$ María Teresa Gramuglio ha señalado magistralmente cómo en esta coexistencia de dos voces narrativas se construye "una dominante imagen de escritor que se escribe y reescribe, a lo largo de la novela, en formas múltiples" (Gramuglio 1997: 771). Pero a pesar de compartir plenamente su análisis de la novela como puesta en escena de la construcción de una imagen de autor, como también su punto de vista de la importancia dada a la serie muerte y renacimiento del autor en el texto, no coincido con su diferenciación entre una concepción poética que muere y otra que gana para imponerse finalmente. A pesar de la alusión en Adán Buenosayres a los famosos "Epitafios" de Martín Fierro, cuya postura se repite sobre todo en el tono festivamente burlón del "Prólogo" y la parodia omnipresente en los primeros libros de la novela, el entierro del poeta Adán no significa la muerte de la estética martinfierrista que, según Gramuglio, debe morir para que nazca el narrador Marechal. Ni el "Cuaderno de Tapas Azules" del Libro VI ni la poética expuesta en la glorieta de Ciro Rossini en el Libro IV, 1 corresponden a la poética vanguardista de la revista Martín Fierro, ni la confrontación de las voces narrativas de L. M. y Adán es teleológica o culmina en el recambio de una poética por otra. Pues aunque aparentemente se pueda diferenciar entre dos posiciones donde una corresponda a un narrador L.M. orientado hacia el futuro y otra a un narrador Adán nostálgico y anacrónico, la relación entre ellos no es hegemónica, sino que recíproca e indecisa, como demostraré a continuación.
} 
un año impreciso de los años veinte (Libro I, 1) y su viaje por las calles de Buenos Aires (Libro II, 1) rumbo a la casa de los Amundsen, donde acontece el gran desengańo del poeta al confrontar la Solveig real con la de su "Cuaderno" (Libro II, 2). Después de la travesía por el bajo de Saavedra (Libro III, 1), el velorio de Juan Robles (Libro III, 2), el banquete en la glorieta de Ciro Rossini (Libro IV, 1) y la visita del prostíbulo en la calle Canning (Libro IV, 2), Adán llega a su casa en la madrugada del 29 de abril (Libro IV, 3) y termina, esta misma noche, su "Cuaderno" (Libro VI, sección 13 y 14). A la mañana siguiente, en un segundo despertar presentado por L. M. al inicio del Libro V, Adán se acuerda de su infancia en Maipú (Libro V, 1), va después a su escuela a impartir clases de literatura clásica (Libro V, 2) y vuelve a su casa (Libro V, 3). La noche del 30 de abril emprende el "Viaje a la Oscura Ciudad de Cacodelphia" en compañía del amigo Schultze, presentado autodiegéticamente por Adán en el Libro VII. La novela se termina, sintagmáticamente, con el famoso encuentro entre Adán y el gusano paleogogo en la última espiral del infierno (final del Libro VII); pero, cronológicamente, con el entierro de Adán el 10 de octubre, ya presentado en el "Prólogo indispensable", donde el narrador que firma "L. M." y otros cinco amigos llevan a la tumba el ataúd de su amigo Adán, tan leve como "la materia sutil de un poema concluido" (Marechal 2013: 91) ${ }^{45}$.

\section{SUPERPOSICIONES DE VOCES, O LA DIALÉCTICA EN REPOSO}

Coulson, sin embargo, no sacó las conclusiones de esta estructura narrativa tan claramente seńalada por ella misma (Coulson 1974); no vio el carácter dialéctico-dialógico de las voces narrativas de Adán Buenosayres, donde la narración de Adán provoca la de L. M. y viceversa. Como en una égloga garcilasiana, las voces se alternan y responden; y como en una novela de Faulkner, se contradicen y presentan imágenes divergentes de una misma realidad, que se quiebra y multiplica al mismo tiempo en la diferentes perspectivas que la constituyen (cfr. al respecto también mi análisis en Hammerschmidt 2015d). Lo que extraña en esta confrontación de voces o imágenes, y lo que marca su ultramodernidad, es su evidente falta de síntesis: ya que -casi como en la imagen-constelación de Benjamin, que interrelaciona tiempos diferentes, o lo-que-ha-sido con el-ahora, en una "Dialektik im Stillstand" ("dialéctica en reposo", en suspenso ${ }^{46}$ )-, estas voces ni se acercan en una

\footnotetext{
${ }^{45}$ Cfr. al respecto también mi artículo "Adán Buenosayres o La violencia de la escritura” (Hammerschmidt 2015b).

46 "Nicht so ist es, daß das Vergangene sein Licht auf das Gegenwärtige oder das Gegenwärtige sein Licht auf das Vergangne wirft, sondern Bild ist dasjenige, worin das Gewesene mit dem Jetzt blitzhaft zu einer Konstellation zusammentritt. Mit anderen Worten: Bild ist die Dialektik im Stillstand. Denn während die Beziehung der Gegenwart zur Vergangenheit eine rein zeitliche ist, ist die des Gewesnen zum Jetzt eine dialektische: nicht zeitlicher sondern bildlicher Natur. Nur dialektische Bilder sind echt geschichtliche, d.h. nicht archaische Bilder. Das gelesene Bild, will sagen das Bild im Jetzt der Erkennbarkeit trägt im höchsten Grade den Stempel des kritischen, gefährlichen Moments, welcher allem Lesen zugrunde liegt" (Benjamin 1991g: 578). Reproduzco la traducción de Luis Fernández Castañeda, Fernando Guerrero e Isidro Herrera Baquero: "No es que lo pasado
} 
progresión teleológica que finalmente logre la sustitución de la una en la otra, ni se congelan en una imagen solidificada, sin movimiento, que se eternizara en un status quo inamovible. Todo al contrario, tal en la fotografía o las imágenes superpuestas del cine vanguardista, en un mismo texto se superponen dos instancias que insisten mutua y simultáneamente en un solo espacio. Así, al poner en escena la lucha por el poder de los discursos, esta novela ultramoderna monta estrategias narrativas y retóricas heterogéneas, premodernas (la creencia en la coincidencia simbólica de las palabras y las cosas de Adán) y posmodernas (la permanente distanciación paródica de la narración y lo narrado y el escepticismo frente a las posibilidades miméticas del lenguaje de L. M.), sin que tome posición unívoca por ninguna. Se yuxtaponen la voz elegíaca y nostálgica de Adán, que busca la vuelta a un paraíso anterior a la ruptura entre el mundo y su designación, y su comentario paródico por L. M., que por su misma parodia critica, pero también repite las posiciones parodiadas, introduciendo la duda sobre su posición frente a lo que presenta ${ }^{47}$. En la confrontación de estas posturas antagónicas, sin embargo, la "dialéctica en reposo" se hace la alegoría de su síntesis imposible, de su eterna grieta, o de su propia indecidibilidad, y no se desmonta únicamente la voz del poeta, sino también la de L. M.: narrador y autor. De esta manera, el texto pone en escena una deposición mutua, una lucha que desemboca en la negación de toda autoridad sobre el texto, y se hace la alegoría de un sacrificio ${ }^{48}$.

\footnotetext{
arroje luz sobre lo presente, o lo presente sobre lo pasado, sino que imagen es aquello en donde lo que ha sido se une como un relámpago al ahora en una constelación. En otras palabras: imagen es la dialéctica en reposo. Pues mientras que la relación del presente con el pasado es puramente temporal, la de lo que ha sido con el ahora es dialéctica: de naturaleza figurativa, no temporal. Sólo las imágenes dialécticas son imágenes auténticamente históricas, esto es, no arcaicas. La imagen leída, o sea, la imagen en el ahora de la cognoscibilidad, lleva en el más alto grado la marca del momento crítico y peligroso que subyace a toda lectura” (Benjamin 2005: 465).

${ }^{47}$ La dualidad entre realismo e idealismo, escepticismo y esencialismo, polifonía y monologismo ha sido cabalmente analizado como oposición entre nominalismo aristotélico/santo-tomasino y realismo platónico/san agustiniano por Norman Cheadle (2000: 67-70).

${ }^{48}$ Como acabo de destacar, este sacrificio es entonces doble. No sólo Adán depende de la voz de L. M.; sino también este, de aquel. Pero además de su mutua dependencia a través de la parodia, también la presencia o ausencia del uno provoca la aparición o muerte del otro. Así como el poeta se entierra al iniciarse la novela, L. M. desaparece al entrar en el texto. Pues de los seis hombres que en el "Prólogo indispensable" llevan el ataúd donde yace Adán ("seis hombres nos internábamos en el Cementerio del Oeste" [Marechal 2013: 91]), solo cinco se nombran: Schultze, Tesler, Pereda, Franky Amundsen y Del Solar - los mismos que en los Libros I a V acompañan al poeta, y que en el Libro VII se encuentran junto a él en los diversos círculos infernales de la Oscura Ciudad de Cacodelphia ideada por Schultze. L. M., por el contrario, que pretende ser el amigo más íntimo del muerto, el amigo al que Adán le dejó en herencia sus escritos personales y poéticos, no aparece nunca más en la acción narrada, y cambia de la primera a la tercera persona en el pasaje del "Prólogo indispensable" al Libro I. Así que la novela no solo narra la muerte del poeta Adán, sino también la del narrador L.M., que debe desaparecer para que nazca la novela.
} 


\section{Pó́ticas EN LUCHa}

La poética representada por Adán se basa en el "lenguaje adánico" ${ }^{49}$, es decir el intento de remotivar la relación arbitraria entre las palabras y las cosas y de identificar las cosas por sus nombres. Esta poética busca el acercamiento máximo o la coincidencia entre el signo y su referente en una estética idealista que ve en la belleza la posibilidad de un ascenso hacia lo verdadero y bueno ${ }^{50}$. María Rosa Lojo (1987) ha demostrado que Adán, al discurrir en la glorieta de Ciro Rossini -el 'simposio sobre la belleza'51 - sobre la imposibilidad del "disparate" en la poesía ${ }^{52}$, brinda una justificación 'metafísica' y posterior de la metáfora, que (a diferencia de la metáfora vanguardista ${ }^{53}$ ) no apunta a lo absurdo y la distancia máxima entre las áreas que implícitamente se comparan en el tertium comparationis, sino a una coincidentia oppositorum donde lo ridículo y lo sublime convergen. Esta teoría, solo en aparente relación con la metáfora martinfierrista, es de evidente procedencia (neo) platónica ${ }^{54}$, como lo explica el mismo Adán a sus amigos. Según su teoría, el poeta debe evadirse de toda apariencia material del mundo y concentrar su capacidad mimética en la

${ }^{49}$ Para el "lenguaje adánico" y su caotización babélica, cfr. "Da Adamo alla confusio linguarum" (Eco 1993: 1330). El hecho de que el llamado lenguaje adánico se encuentre en un punto de indecisión entre la creencia en una correspondencia res-verba esencialista y la idea del lenguaje como convención arbitraria parte, según Eco, de la ambivalente versión de la Vulgata, en la que se dice que "Adamo ha chiamato i vari animali nominibus suis, e a tradurre 'coi loro nomini' non si risolve nulla [...]. Ogni nome dato da Adamo è il nome che doveva avere l'animale a causa della sua natura o quello che il Nomoteta ha deciso arbitrariamente di assegnarli, ad placitum, istaurando così una convenzione?” (Eco 1993: 14).

${ }^{50}$ No corresponde, entonces, a la concepción vanguardista de la metáfora o la estética martinfierrista, como lo pretende Gramuglio (1997).

${ }^{51}$ Como se sabe, los conceptos desarrollados allí son muy cercanos a los conceptos desarrollados por Adán en su "Cuaderno de Tapas Azules" y por el mismo Marechal en su Descenso y ascenso del alma por la belleza (cfr. Marechal 2016). Esta teoría estética la desarrolla Marechal durante más de treinta años, al publicar un primer esbozo en La Nación en 1933 y publicando Descenso y ascenso del alma por la belleza en forma de libro por primera vez en 1939, después en 1950 y, en su forma definitiva, también en 1965 (cfr. al respecto Maturo 1999: $35-52)$.

${ }^{2}$ Cfr. p. ej. la siguiente cita - una mínima parte del largo tratado poético de Adán presentado a los amigos borrachos en la glorieta: "Ergo [...], el disparate no es de este mundo [...]. Nómbreme, por ejemplo, dos cosas que nada tengan que ver entre sí, y asócielas mediante un vínculo que sabemos imposible en la realidad. De primera intención, en esos dos nombres la inteligencia ve dos formas reales, bien conocidas por ella. Luego viene su asombro al verlas asociadas por un vínculo que no tienen en el mundo real. Pero la inteligencia no es un mero cambalache de formas aprehendidas, sino un laboratorio que las trabaja, las relaciona entre sí, las libera en cierto modo de la limitación en que viven y les restituye una sombra, siquiera, de la unidad que tienen en el Intelecto Divino. Por eso la inteligencia, después de admitir que la relación establecida entre las dos cosas es absurda en el sentido literal, no tarda en hallarle alguna razón o correspondencia en el sentido alegórico, simbólico, moral, anagógico..." (Marechal 2013: 356).

${ }^{53}$ Como Marechal la había practicado sobre todo en los años 20, en el contexto martinfierrista.

${ }^{54}$ Cfr. al respecto Maturo (1999) y Cheadle (2000). 
abstracción, la forma, que capta, no la existencia contigua y perecedera del mundo, sino la esencia misma de las cosas, que revela su unidad secreta. El modus operandi del poeta consiste entonces en la imitación por denominación. Es así que se acerca a la creación divina y adánica de crear nombrando. Abstrae de lo concreto, visibiliza su esencia y la nombra en el pars pro toto que es el acto poético según Adán. La palabra contiene la cosa, los verba son las res, y no hay diferencia entre la escritura adánica y el mundo al que llama a su existencia mediante su arte poética.

Sin embargo, esta abstracción por la forma a la que aspira Adán, tiene su meta explícita en la superación de la temporalidad y de la muerte de su objeto; por esto, el punto de partida del proceso poético no es un mundo ya idealizado, sino siempre la contingencia circundante de la que pretende escapar ${ }^{55}$. Así, después de las varias fases poéticas (neo) platónicas descritas por Adán en la glorieta de Ciro Rossini, que implica la superación de lo contingente por las fases de la inspiración y expiración poética, de la caída ad intra y ad extra (cfr. Hammerschmidt 2015b: 276-278), el poeta encuentra la estructura abstracta que contiene el todo, que combina el signo y su significado y que se hace denominación adánica, paradisíaca, por procedimiento simbólico:

[V]iendo yo lo mucho que se arriesgaba su hermosura al resplandecer en un barro mortal, fui extrayendo de aquella mujer todas las líneas perdurables, todos los volúmenes y colores, toda la gracia de su forma; y con los mismos elementos (bien que salvados de la materia) volví a reconstruirla en mi alma según peso, número y medida; y la forjé de modo tal que se viera, en adelante, libre de toda contingencia y emancipada de todo llanto (Marechal 2013: 500-501).

Aquí, lo físico y la forma se unen en una relación sinecdóquica, en la que el signo, la representación, como parte, contiene el todo, que se traduce por la congruencia lograda entre la palabra y la cosa. Es en este sentido que el recurso retórico por antonomasia de Adán es el símbolo, ya que permite encontrar las palabras que les corresponden a las cosas, que las traducen, dicen, eternizan y por esto crean en el acto mismo de la denominación.

\footnotetext{
${ }^{55}$ De esta manera, el proceso poético propuesto por Adán no es martinfierrista, y no se basa en la metáfora vanguardista. Sin embargo, tampoco recurre a la pura abstracción, como lo hubiera podido sugerir el camino que toma la poesía del mismo Marechal desde los años 1920 a los años 1930 según los análisis de Monteleone (2015) y Foffani (2015). En su estudio de la poesía marechaliana de los años veinte, Jorge Monteleone ha observado una dialéctica que va de la dinamia de la contradicción al dinamismo de los contrarios hasta el hallazgo del arquetipo (cfr. Monteleone 2015); Enrique Foffani, sin embargo, al estudiar la poesía de Marechal de los años treinta, ha subrayado que, en su intento de "sustraerse de la subjetivación romántica", Marechal recurrió a la recuperación del "goce de la santidad y, conjuntamente, el modo medieval de pensar haciendo que se perciban [...] conceptos abstractos como si fueran objetos concretos y perceptibles a los sentidos" (Foffani 2015: 155). Sin embargo, a diferencia de estas posiciones en la poesía de Marechal, en la novela marechaliana de 1948, la abstracción poética de la que parte Adán siempre se relaciona a un tertium comparationis que se destaca entre lo concreto y lo abstracto, entre lo perecedero y lo esencial, entre el cuerpo y su forma, y nunca parte de la abstracción para llegar a la realidad concreta solo a posteriori.
} 
Así, la creación poética de Adán, que se basa en un movimiento doble hacia la recuperación de la unidad adánica perdida por la internalización, dispersión, abstracción y concretización de las distintas formas en su representación simbólica, llega a la síntesis entre las palabras y las cosas y, por ende, a una coincidencia sintética consigo misma. Es en este mundo premoderno del símbolo donde, en palabras de Paul de Man, parece "posible hacer que la imagen coincidiera con la sustancia, puesto que la sustancia y su representación no difieren en su manera de ser sino sólo en su extensión: ambas son la parte y el todo del mismo conjunto de categorías" (de Man 1991: 229). No hay distancia entre la expresión simbólica y lo que denomina Adán; todo al contrario de la narración de L. M., que se caracteriza por su permanente parábasis y ruptura entre lo representado y el mismo proceso de la representación.

L. M., el narrador que cambia de la primera a la tercera persona al terminar el "Prólogo indispensable", se pone en escena tanto como narrador tradicional, omnisciente, editor ficticio del legado de su amigo, y biógrafo que presenta dos días de la vida de Adán como introducción (y explicación) a los escritos del poeta difunto. En su descripción del camino de Adán por las calles, los barrios y arrabales de Buenos Aires, constantemente se burla no solo de su 'héroe', sino también de todos los personajes, circunstancias y sobre todo discursos con los que se topa, citando y distanciándose constantemente de la política cultural porteña de los años 20 hasta los $40^{56}$. Así, el procedimiento poético-narrativo de los libros de L.M. no es ni el símbolo ni la sinécdoque, sino la parodia - en cuanto modalidad expresiva que simultáneamente forma parte de un texto y funciona como su comentario crítico (según lo ha planteado Linda Hutcheon [1989] para la literatura posmoderna) ${ }^{57}$. Esta parodia impide toda coincidencia entre los signos y un significado, ya que constantemente oscila entre un 'hablar con' y un 'hablar contra' por la imbricación de cita y crítica, homenaje y burla, en el mismo procedimiento ${ }^{58}$.

\footnotetext{
${ }^{56}$ Sean la estética vanguardista, criollista, folletinesca, la búsqueda por la identidad nacional o la 'argentinidad': todas estas posturas aparecen en los libros de L. M. como puestas en escena fantasmáticas, espectrales o ridículas que en su misma pluralidad pasajera demuestran su insustantibilidad (cfr. mi nota 38). Con respecto a que la ciudad de Buenos Aires representada corresponde más a los años 40 que a los años 20, cfr. Saítta (2004). Con respecto a las diferencias de la concepción poética de Marechal en Adán Buenosayres y su poética de los años veinte y treinta, ver arriba.

${ }^{57}$ Con respecto a la presencia de la parodia en Marechal, cfr., entre otros, los estudios de Bravo Herrera (p. ej. 2015a y 2015b), o mis propios trabajos (Hammerschmidt 1993a y Hammerschmidt 1993b).

${ }^{58}$ Winfried Freund, en su reconstrucción etimológica de "parodia", destaca la ambivalencia del elemento preposicional 'para', que puede entenderse como adición o adversión. Ya por su etimología, entonces, "parodia" puede entenderse como 'canto con' o 'canto contra' (cfr. Freund 1981).
} 


\section{Alegoría y (De)posición aUtorial}

Obviamente entonces, entre Adán y L. M. nunca se llega a una síntesis, coincidencia o superación de una de las voces en la otra. Sus textos se alternan, según había demostrado la reconstrucción cronológica de la novela, marcan su incongruencia como fisura infranqueable, "dialéctica en reposo" o constelación sin telos ni fin", y exponen el hueco del que están sujeto. Así, la relación entre Adán y L. M. a su vez constituye una relación retórica: conforman una alegoría de la escritura, que ostenta siempre su 'hablar de otro modo' ${ }^{60}$ e implica la simultaneidad e indecidibilidad de un significado literal y otro, figurado.

Ya desde el Trauerspiel de Walter Benjamin (1991a), y a pesar de su aparente pertenencia a la Edad Media o el Barroco, la alegoría constituye una de las figuras centrales de la modernidad y ha sido considerada su 'armadura ${ }^{61}$. Si la entendemos, con Paul de Man, como una figura retórica de la temporalidad que indica la imposibilidad de una experiencia presente y que se pierde en un pasado o futuro a su vez inalcanzables por imaginarios (de Man 1991), es en la alegoría que forman Adán y L. M. que se abre la disyuntura del tiempo moderno, el "vacío de una diferencia temporal" (de Man 1991: 230), o su eterna différance. Adán y L. M. -como los dos lados indecidibles de un significado literal y otro figurativo que se enfrentan en la alegoría-, en vez de acercarse para llegar a una síntesis, siempre ostentan la imposibilidad de una congruencia entre res y verba, significante y significado, sujeto y objeto - o personaje y autor, por lo que finalmente también significan la "dialéctica en reposo" del propio autor Leopoldo Marechal en su diferencia y posición excéntrica en relación al texto y contexto al que se refiere ${ }^{62}$.

\footnotetext{
${ }^{59}$ Hago acordar que entre el último libro y el prólogo se abre un hiato indeterminado (cfr. Navascués 1992a, 101, 125, 261-261; Cheadle 2000, 24), y que no se sabe ni cuándo ni cómo (ni sí) Adán salió del infierno, ni qué pasó con L.M., íntimo amigo de Adán según el prólogo, al iniciarse la narración de los libros I a VII.

${ }^{60}$ Cfr. la etimología de "alegoría (en griego allegoría, de álei, «de otro modo» y agoréuo «hablo»)" (Mortara Garavelli 2000: 296).

${ }^{61}$ Cfr. la famosa constatación de Benjamin en su "Zentralpark" / "Parque central": "Die Allegorie ist die Armatur der Moderne" (Benjamin 1991d; en la traducción de Alfredo Brotons Muñoz: "La alegoría es la armadura de lo moderno" [Benjamin 2008: 290]): porque subraya la diferencia entre 'forma' y 'contenido' (tan unidas en la concepción romántica anti-alegórica); porque evita un regreso al mito de la unidad; porque ostenta su artificialidad en la expuesta arbitrariedad de la relación entre signo y significado; y finalmente porque expone la alta tensión que se establece entre ellos.

${ }^{62}$ Cfr. -en un sentido más pragmático- también la dimensión autobiográfica que adopta la novela - no solo porque L. M. lleva los iniciales del mismo Leopoldo Marechal, sino también por las evidentes alusiones a circunstancias de la historia vital de Marechal que se inscriben a Adán Buenosayres: p. ej. el pasado martinfierrista o los recuerdos de vacaciones de infancia pasadas en Maipú, la integración en clave de muchos de los antiguos compañeros de ruta (como sobre todo Borges, Scalabrini Ortiz, Jacobo Fijman, Xul Solar...), los viajes a Europa y la crisis espiritual de los años 30, o la incorporación y ridiculización de los propios poemas de Marechal de los años 1922 hasta 1940.
} 
Pues la alternancia de las voces narrativas de L. M. y Adán implica la simultánea puesta en escena y anulación del retrato del escritor y la mutua deposición de las imágenes autoriales que la misma novela elabora. La imagen del narrador L. M., basada en la burla, versatilidad y difuminación del sentido, y la del poeta Adán, que busca recrear la constancia y eternidad de un paraíso perdido, se ponen mutuamente en peligro, conformando una "dialéctica en reposo" o alegoría de su síntesis imposible, de su gran paradoja ultramoderna y de su indecidibilidad. Por la constante superposición de un eje horizontal -el viaje de Adán por Buenos Aires, presentado por L. M. en una proliferación paródica que rinde homenaje y se burla del protagnista en su flânerie y odisea por un mundo que el poeta (neo) platónico ya no comprende- y un eje vertical -el viaje como búsqueda de una recuperación del sentido perdido, sintetizado en la teoría poética de Adán y su añoranza de un nuevo idioma adánico- se cristaliza la tensión o el entrecruzamiento entre las figuras autoriales en la alegoría de la cruz: ya no como significado teológico, sino como "crucificación, borradura del significado, puesta en riesgo de la verdad por el lenguaje" (Cricco et al. 1985: 105) "tachadura" (Cricco et al. 1985: 98-106), mutua destitución, aniquilación, autodestrucción. $\mathrm{Y}$ es en esta alegoría de la cruz, mutua deposición o sacrificio, que se inscribe, paródica y adánicamente, la figura del autor Leopoldo Marechal a través de una imitatio Christi.

\section{IMITATIO CHRISTI Y AUTORÍA SACRIFICIAL}

Al final del Libro $\mathrm{V}$-fin de los libros narrados por L. M., y momento del regreso a casa de Adán, después de dos días de infructuosas búsquedas y aventuras-, el poeta cansado por sus vanas andanzas se detiene ante la iglesia del barrio, frente al Cristo de la Mano Rota, del que espera "el anuncio de Alguien que tal vez lo haya escuchado" (Marechal 2013: 466). Sin embargo, la añorada respuesta parece no llegar; otra vez la búsqueda aparenta ser inútil, y la noche oscura se hace "el silencio que mana del cosmos" (Marechal 2013: 466): "Su voluntad se quiebra entonces: desciende su mirada, gira él sobre sus talones y permanece allí como anonadado, frente al círculo de luz que un farol proyecta en los adoquines de la calle" (Marechal 2013: 466). Es aquí que la narración de L. M. parece haber abandonado toda parodia y acercado su tono a la angustia (casi arltiana) de Adán. No obstante, de repente la atmósfera pesadillesca se rompe, y de la soledad apagada surge la vida, y con ella la parodia: "Un perrito negro andaba por allí, sentándose acá y allá sobre sus patas traseras, gimiendo y olfateando lugares, en el tormento de una deposición trabajosa" (Marechal 2013: 466) ${ }^{63}$. Es esta imagen casi final de los libros de L. M. -el poeta en espera de respuestas que no llegan, y el perrito negro que no logra ir de cuerpo ${ }^{64}-$ que quizás mejor escenifique la incongruencia de

\footnotetext{
${ }^{63}$ En su reminiscencia al perro de Fausto, este perro de Marechal obtiene también calidades infernales y conecta el final del libro $V$ con el gusano con el que termina el libro VII.

${ }^{64}$ También esta situación final, con su ilustración de la constipación, se acerca al final del Libro VII, donde el poeta se queda detenido en el infierno, enfrentado al gusano "[s]olemne como pedo de inglés" (Marechal 2013: 748).
} 
los signos, su "dialéctica en reposo", y el dilema autodestructivo de esta novela ultramoderna que constantemente instala y sacrifica su significado. Y es también en esta imagen de la constipación o "deposición" que Marechal, en palabras de Carlos Gamerro, enlaza

en una sola figura o continuo las campanas celestes y el perrito constipado, como en las metáforas vanguardistas de su poesía, aunque en este caso el vínculo es menos arbitrario de lo que parece: ,deposición' es el término técnico, en la iconografía cristiana, para las imágenes del descenso de Cristo de la cruz, y no debe ser casualidad que [...] [e]l juego con la palabra continuará en "El poeta depuesto" y también en Megafón (Gamerro 2015: 504).

La indecidibilidad de lo heterogéneo, donde lo uno constantemente se transforma en lo otro sin llegar a 'transubstanciarse' completamente, donde signos y referentes buscan su identidad y siempre marcan su incongruencia, y donde una plenitud o experiencia dejan de presenciarse por una permanente différance que las imposibilita, es la condena, pero también el desafío y la oportunidad del autor que se expone a las paradojas de la modernidad trabajando su anti- o ultramodernidad, haciendo el trabajo de duelo y a la vez de resistencia contra sus efectos. Marechal, en su abierta inclinación hacia lo popular, múltiple y cotidiano, como en el simultáneo deseo de su transfiguración re-presentacional que a la vez sabía imposible, respondió a esta tendencia anti- o ultramoderna de la modernidad a transgredirse constantemente. Por esto su escritura, como también su imagen autorial, solo pudo constituirse en su propia aniquilación o autosacrificio, en una imitatio Christi paródica o alegoría indecidible que dice y desdice la esperanza de una resurrección en la palabra. Así, la alegoría final de Adán Buenosayres, su telos y fin que ya por la estructura del texto evidencian no serlo, consiste en la ostentación del signo a la vez doble y vacío que se instala en la ruina de la significación. En esta superposición de la imitatio Christi y la constipación, la crucifixión y la deposición, Adán y L. M., se ilustra la ultramodernidad del autor Leopoldo Marechal: la puesta en escena de la eterna diferencia entre el mundo y su representación a través de una alegoría que habla de la deposición y muerte del autor en el momento mismo de escenificarla y así resucitar-y deponer- al que se sacrifica.

\section{Conclusiones}

De esta manera, la co-presencia de imágenes contradictorias del autor -de un poeta premoderno y (neo)platónico, que cree en la correspondencia de las palabras y las cosas, y de un narrador posmoderno y paródico, que pone en escena un mundo y lo desdice al mismo tiempo- significa la constante deposición operada por la escritura y la crucificación alegórica del autor. Es entonces a través de una dialéctica sin fin que las imágenes autoriales enfrentadas en Adán Buenosayres se deconstruyen mutuamente para culminar en una alegoría tanto literal y paródica de la imitatio Christi. Así, "la alegoría aparece [al mismo 
tiempo] como una modalidad diacrónica capaz de engendrar duración, i.e., la ilusión de una continuidad que reconoce ser ilusoria" (de Man 1991: 250), y simultáneamente "existe completamente dentro de un tiempo ideal que no es nunca el aquí y ahora sino siempre un pasado o un futuro sin final" (de Man 1991: 250).

Al entrecruzarse Adán y L. M., pasado y futuro, en la misma figura (cuerpo - muerte - cruz - deposición - resurrección), se ilustran las paradojas de una escritura ultramoderna que inscribe y aniquila a la vez lo que dice, sustrayéndose de esta manera de cada sensación de presente. La función mesiánica, que Walter Benjamin, a pesar de todo, todavía podía atribuirle al arte moderno, ya no opera en Adán Buenosayres, por su misma defensa explícita como la personifica la poética de Adán y su simultánea deconstrucción y sacrificio en una parodia constante. De esta manera, la novela practica una renuncia a toda salvación posible de las heridas producidas por la modernidad: sea esta individual, estética-poética, o social. Así como el sujeto pierde su capacidad de la experiencia inmediata, la literatura no puede recomponer o re-presentar un mundo heterogéneo que se caracteriza por la mezcla, y menos aún obsequiarle mitos de una identidad cultural o nacional que sobrevivan el momento de su puesta en escena. De esto el texto se regocija, y a la vez lo deplora en un duelo literal y paródico.

Por consiguiente, parece haber sido por esta radicalidad escrituraria ultramoderna, y no solo por causas ideológicas, que la estética narrativa de Marechal debió silenciarse hasta bien entrado los ańos sesenta, momento en que se da a conocer la llamada "nueva novela latinoamericana" que debe tanto a Adán Buenosayres (cfr. Hammerschmidt 1993a y 1993b). Fue la co-presencia de lo heterogéneo, esta 'pan-visión' de conceptos premodernos y posmodernos, la búsqueda de un pasado perdido y su simultánea parodia en una alegoría indecidible que expone su propia différance y vacuidad, la que conforma la ultramodernidad sacrificial del autor Leopoldo Marechal: autor paradigmático de la modernidad literaria argentina, y a la vez su víctima y "poeta depuesto".

\section{OBRAS CITADAS}

Alazraki, Jaime. 1976. "Tlön y Asterión: metáforas epistemológicas". En: Jorge Luis Borges. El escritor y la crítica. Ed. Jaime Alazraki. Madrid: Taurus. 183-203.

Amícola, José. 2014. "Rayuela antes y después". Inti 79-80. 71-83.

Bakhtine, Mikhail. 1970. L'ouvre de François Rabelais et la culture populaire au Moyen Age et sous la Renaissance. Trad. Andrée Robel. Paris: Gallimard.

- - - 1978. Esthétique et théorie du roman. Trad. Daria Olivier. Paris: Gallimard.

Barcia, Pedro Luis. 1994. "Viaje a la Oscura Ciudad de Cacodelphia". En: Leopoldo Marechal. Adán Buenosayres. Ed. Pedro Luis Barcia. Madrid: Clásicos Castalia. 74-92.

Barrenechea, Ana María. 1957. La expresión de la irrealidad en la obra de Jorge Luis Borges. México: El Colegio de México.

Barthes, Roland. 1982. "L'effet de réel" [1964]. En: Roland Barthes et al. Littérature et 
réalité. Paris: Seuil. 81-90.

Baudelaire, Charles. 1986 [1863]. "Le peintre de la vie moderne". En: Charles Baudelaire. Écrits esthétiques. Ed. Jean-Christophe Bailly. Paris: Union générale d'édition (Colección "10/18"). 360-404.

Baudrillard, Jean. 1976. L'échange symbolique et la mort. Paris: Gallimard.

Baur, Sergio, Juan Manuel Bonet y Rafael Flores. 2001. Literatura argentina de vanguardia: 1920-1940. Madrid: Casa de América.

Benjamin, Walter. 1991a. Der Ursprung des deutschen Trauerspiels. [1925]. En: Walter Benjamin. Gesammelte Schriften I/1. Ed. RolfTiedemann y Hermann Schweppenhäuser. Frankfurt/M.: Suhrkamp. 203-430.

- - -. 1991b. Das Kunstwerk im Zeitalter seiner technischen Reproduzierbarkeit. [1936]. En: Walter Benjamin. Gesammelte Schriften I/2. Ed. Rolf Tiedemann y Hermann Schweppenhäuser. Frankfurt/M.: Suhrkamp. 431-469 ("Erste Fassung”).

- - -. 1991c. "Über einige Motive bei Baudelaire". [1939]. En: Walter Benjamin. Gesammelte Schriften I/2. Ed. Rolf Tiedemann y Hermann Schweppenhäuser. Frankfurt/M.: Suhrkamp. 605-653.

- - -. 1991d. "Zentralpark". [1939]. En: Walter Benjamin. Gesammelte Schriften I/2. Ed. RolfTiedemann y Hermann Schweppenhäuser. Frankfurt/M.: Suhrkamp. 655-690. - - . 1991e. "Erfahrung und Armut". [1933]. En: Walter Benjamin. Gesammelte Schriften

II/1. Ed. Rolf Tiedemann y Hermann Schweppenhäuser. Frankfurt/M.: Suhrkamp. 213-219.

- - -. 1991f. "Der Erzähler. Betrachtungen zum Werk Nikolai Lesskows". [1936]. En: Walter Benjamin. Gesammelte Schriften II/2. Ed. Rolf Tiedemann y Hermann Schweppenhäuser. Frankfurt/M.: Suhrkamp. 438-465.

- - -. 1991g. Das Passagen-Werk. En: Walter Benjamin. Gesammelte Schriften V/1. Ed. Rolf

Tiedemann y Hermann Schweppenhäuser. Frankfurt/M.: Suhrkamp.

- - -. 2005. Libro de los Pasajes. Trad. Luis Fernández Castañeda, Fernando Guerrero e Isidro Herrera Baquero. Madrid: Akal.

- - . 2008. "Parque central”. En: Walter Benjamin. Obras I/2. Trad. Alfredo Brotons Muñoz. Madrid: Abada. 261-302.

Blanchot, Maurice. 1949. "La littérature et le droit à la mort". En: Maurice Blanchot. La part du feu. Paris: Gallimard. 291-331.

Blanco, Mariela. 2015a. "Ficciones de la conjetura. La nación como invención en Borges". LiRiCo 12, s.p. Web. 28 de abril de 2017. http://lirico.revues.org/1916.

- - -. 2015b. "La invención de la Nación y el Pueblo en Adán Buenosayres". En: Peronismo y representación. Escrituras, imágenes y políticas del pueblo. Ed. Carina González. Buenos Aires: Final Abierto. 33-56.

Borges, Jorge Luis. 1921. "Ultraísmo". Nosotros 39. 466-471.

Bravo Herrera, Fernanda. 2015a. "Parodias y reescrituras de tradiciones literarias en Leopoldo Marechal". En: Leopoldo Marechal y la fundación de la literatura argentina moderna. Ed. Claudia Hammerschmidt. Potsdam-London: INOLAS. 411-431. 
- -. 2015b. Parodias y reescrituras de tradiciones literarias y culturales en Leopoldo Marechal. Buenos Aires: Corregidor.

Bürger, Peter. 1992. Prosa der Moderne. Frankfurt/M.: Suhrkamp.

Calabrese, Elisa. 2005/2006. "Las revistas de Abelardo Castillo. Un proyecto cultural alternativo". CELEHIS-Revista del Centro de Letras Hispanoamericanas 17. 39-57.

Carbone, Rocco. 2006. "Voces al margen del discurso hegemónico: una 'zona alternativa' entre Boedo y Florida". En: De márgenes y silencios. Homenaje a Martin Lienhard. Ed. Annina Clerici y Marília Mendes. Madrid-Frankfurt/M.: Iberoamericana-Vervuert. 191-206.

- -. 2009. "Malos modales: tra(d)iciones de Piglia a Arlt". Confluenze. Rivista di studi iberoamericani 1.2. 174-191.

Castillo, Abelardo. 2007 [1997]. "Leopoldo Marechal". En: Abelardo Castillo. Ser escritor. Buenos Aires: Seix Barral.

Cavallari, Héctor. 1981. Leopoldo Marechal: el espacio de los signos. México: Universidad Veracruzana.

Cheadle, Norman. 2000. The Ironic Apocalypse in the Novels of Leopoldo Marechal. London: Tamesis.

Colla, Fernando. 1991. Leopoldo Marechal: la conquista de la realidad. Córdoba: Alción.

Compagnon, Antoine. 1990. Les cinq paradoxes de la modernité. Paris: Seuil.

- - -. 2016 [2005]. Les antimodernes, de Joseph de Maistre à Roland Barthes. Paris: Gallimard.

Corral, Rose. 1992. El obsesivo circular de la ficción. Asedios a "Los siete locos" y "Los Lanzallamas" de Robert Arlt. México: Fondo de Cultura Económica.

Cortázar, Julio. 1994 [1949]. "Leopoldo Marechal: Adán Buenosayres". En: Julio Cortázar. Obra critica/2. Ed. Jaime Alazraki. Madrid: Alfaguara. 167-176.

Coulson, Graciela. 1974. Marechal, la pasión metafisica. Buenos Aires: García Cambeiro.

Cricco, Valentín et al. 1985. Marechal, el otro. La escritura testada de "Adán Buenosayres". Buenos Aires: Ediciones de la Serpiente.

De Man, Paul. 1969. "The Rhetoric of Temporality". En: Interpretation: Theory and Practice. Ed. Charles S. Singleton. Baltimore: Johns Hopkins Press. 173-209.

- - - 1991. "Retórica de la temporalidad". En: Paul de Man. Visión y ceguera: ensayos sobre la retórica de la crítica contemporánea. Puerto Rico: Editorial de la Universidad de Puerto Rico. 207-253.

De Toro, Alfonso. 1999. “¿Paradoja o rizoma? 'Transversalidad' y 'escriptibilidad' en el discurso borgeano”. En: El siglo de Borges: Retrospectiva-Presente-Futuro. Eds. Alfonso de Toro y Fernando de Toro. Frankfurt/M.: Vervuert.

Deleuze, Gilles. 1969. "Platon et le simulacre". En: Gilles Deleuze. Logique du sens. Paris: Minuit. 292-307.

Derrida, Jacques. 1967. De la grammatologie. Paris: Minuit.

- - -. 1972. "Sémiologie et grammatologie. Entretien avec Julia Kristeva". En: Jacques Derrida. Positions. Paris: Minuit. 25-50.

Eco, Umberto. 1962. Opera aperta. Forma e indeterminazione nelle poetiche contemporanee. 
Milano: Bompiani.

- - - 1993. La ricerca della lingua perfetta nella cultura europea. Roma-Bari: Laterza.

Foffani, Enrique. 2015. "Bajo el signo de Sophia. La poesía de Leopoldo Marechal en la década del 30". En: Leopoldo Marechal y la fundación de la literatura argentina moderna. Ed. Claudia Hammerschmidt. Potsdam-London: INOLAS. 137-166.

Freund, Winfried. 1981. Die literarische Parodie. Stuttgart: Metzler.

Gamerro, Carlos. 2015. "Marechal entre Joyce y Perón". En: Leopoldo Marechal y la fundación de la literatura argentina moderna. Ed. Claudia Hammerschmidt. PotsdamLondon: INOLAS. 489-521.

Garramuño, Florencia. 2009. Experiencia opaca. Literatura y desencanto. Buenos Aires: Fondo de Cultura Económica.

Genette, Gérard. 1987. Seuils. Paris: Seuil.

Gilman, Claudia. 1989. "Polémicas II" [Florida y Boedo]. En: Yrigoyen, entre Borges y Arlt (1916-1930). Ed. Graciela Montaldo. Vol. VII (de Historia social de la literatura argentina, ed. David Viñas). Buenos Aires: Contrapunto. 49-72.

Gramuglio, María Teresa. 1997. "Retrato del escritor como martinfierrista muerto". En: Leopoldo Marechal. Adán Buenosayres. Ed. Jorge Lafforgue y Fernando Colla. Paris: ALLCA XX/Ediciones Unesco (Colección "Archivos"). 771-806.

Grossmann, Rudolf. 1972. "Dantes Spuren in Leopoldo Marechals Roman Adán Buenosayres". En: Interpretation und Vergleich. Festschrift für Walter Pabst. Eds. Eberhard Leube y Ludwig Schrader. Berlin: Erich Schmidt. 53-68.

Gutiérrez-Girardot, Rafael. 1983. Modernismo. Barcelona: Montesinos.

Hammerschmidt, Claudia. 1993a. "Leopoldo Marechal: Adán Buenosayres. El contar paródico para la constitución del sujeto moderno". En: Actas del VII Congreso Nacional de Literatura Argentina (18.-20.08.1993). Tucumán: Facultad de Filosofía y Letras de la Universidad Nacional de Tucumán. 338-345.

- - . 1993b. Leopoldo Marechal, "Adán Buenosayres". Parodistisches Erzählen zur Konstituierung moderner Subjekterfahrung. Köln: Universität zu Köln 1993.

- - -. 2000. "Utopie des Schreibens: Marcel Proust und Leopoldo Marechal". Romanistische Zeitschrift für Literaturgeschichte/Cahiers d'Histoire des Littératures Romanes 26. 359-375.

- - - 2004. “'Argentinidad' zwischen Metapher und Metonymie”. En: Pasajes - Passages Passagen. Homenaje a / Mélanges offerts à / Festschrift für Christian Wentzlaff-Eggebert. Eds. Susanne Grunwald, Claudia Hammerschmidt, Valérie Heinen y Gunnar Nilsson. Sevilla: Secretariado de Publicaciones de la Universidad de Sevilla. 479-494.

- - . 2010. Autorschaft als Züsur. Vom Agon zwischen Autor und Text bei d'Urfé, Rousseau und Proust. München: Wilhelm Fink.

- -. ed. 2015a. Leopoldo Marechal y la fundación de la literatura argentina moderna. Potsdam-London: INOLAS.

- -. 2015b. "Adán Buenosayres o La violencia de la escritura". En: Leopoldo Marechal y la fundación de la literatura argentina moderna. Ed. Claudia Hammerschmidt. Pots- 
dam-London: INOLAS. 261-279.

- - - 2015c. "Tendencias en lucha. Adán Buenosayres entre lo culto y lo popular o El difícil camino hacia una nueva estética”. En: Literatura latinoamericana entre lo culto y lo popular. Ed. Christian Wentzlaff-Eggebert. Köln: Kölner Beiträge zur Lateinamerika-Forschung. 152-168.

- - . 2015d. "La muerte del autor en Adán Buenosayres de Leopoldo Marechal". Amerika. Mémoires, identités, territoires 12, s.p. Web. 5 de mayo de 2017. http://amerika.revues.org/5884.

- - . 2016. "Rayuela de Julio Cortázar y Adán Buenosayres de Leopoldo Marechal: Una relación a larga distancia”. En: Julio Cortázar y Adolfo Bioy Casares. Relecturas entrecruzadas. Ed. Roland Spiller. Berlin: Erich Schmidt. 127-138.

Hernaiz, Sebastián. 2007. "Adán Buenosayres: la armonización tutelada”. En: El peronismo clásico (1945-1955). Descamisados, gorilas y contreras. Ed. Guillermo Korn (= Vol. IV de Literatura argentina siglo XX, ed. David Viñas). Buenos Aires: Paradiso. 125-139.

Herrera Montero, Bernal. 1997. Arlt, Borges y cía.: narrativa rioplatense de Vanguardia. San José: Universidad de Costa Rica.

Hutcheon, Linda. 1989. The Politics of Postmodernism. London-New York: Routledge.

King, John. 1986. Sur. A Study of the Argentine Literary Journal and its Role in the Development of a Culture, 1931-1970. Cambridge: Cambridge UP.

Kleinschmidt, Erich. 1992. Gleitende Sprache. Sprachbewusstsein und Poetik in der literarischen Moderne. München: Iudicium.

Kofman, Sarah. 1985. La mélancholie de l'art. Paris: Galilée.

Lojo, María Rosa. 1987. "La metáfora, ruptura de límites ontológicos, en Días como flechas, de Leopoldo Marechal". Estudios Filológicos 22. 47-58.

Lyotard, Jean-François. 1979. La condition postmoderne: rapport sur le savoir. Paris: Minuit.

Macciuci, Raquel. 2015. "La biblioteca hispana de Leopoldo Marechal en Adán Buenosayres. Quevedo, Larra, Cacodelphia y más allá la emigración...”. En: Leopoldo Marechal y la fundación de la literatura argentina moderna. Ed. Claudia Hammerschmidt. Potsdam-London: INOLAS. 419-446.

Marechal, Leopoldo. 1966. "Claves de Adán Buenosayres". En: Leopoldo Marechal. Cuaderno de navegación. Buenos Aires: Sudamericana. 121-141.

- - . 1984. Adán Buenosayres. $7^{a}$ ed. Buenos Aires: Editorial Sudamericana.

- - - 1994. Adán Buenosayres. Ed. Pedro Luis Barcia. Madrid: Clásicos Castalia.

- - . 1997. Adán Buenosayres. Ed. Jorge Lafforgue y Fernando Colla. Paris: ALLCA XX/ Ediciones Unesco (Colección "Archivos").

- - -. 2008. "El Poeta Depuesto". En: Leopoldo Marechal. Cuaderno de Navegación. Barcelona: Seix Barral (Colección "Biblioteca Breve"). Ed. aumentada. 147-165.

- - - 2013. Adán Buenosayres. Ed. Javier de Navascués. Buenos Aires: Corregidor.

- - - 2014. Obra poética. Ed. María de los Ángeles Marechal. Buenos Aires: Leviatán.

- - . 2016. Descenso y Ascenso del Alma por la Belleza. Buenos Aires: Vórtice.

Marechal, María de los Ángeles. 2016. "Bio-cronología de Leopoldo Marechal". En: 
Leopoldo Marechal. Descenso y Ascenso del Alma por la Belleza. Buenos Aires: Vórtice. 149-196.

Martínez Pérsico, Marisa. 2013. Leopoldo Marechal entre la cuerda poética y la cuerda humorística. Città di Castello: Edizioni Nuova Prhomos.

Masiello, Francine. 1986. Lenguaje e ideología. Las escuelas argentinas de vanguardia. Buenos Aires: Hachette.

Maturo, Graciela. 1999. Marechal, el camino de la belleza, Buenos Aires: Biblos.

Monteleone, Jorge. 2015. "De la dinamia al arquetipo. La poesía primera de Leopoldo Marechal (1922-1929)". En: Leopoldo Marechal y la fundación de la literatura argentina moderna. Ed. Claudia Hammerschmidt. Potsdam-London: INOLAS. 109-136.

Mortara Garavelli, Bice. 2000. Manual de retórica. Trad. María José Vega. Madrid: Cátedra. Musil, Robert. 1978 [1943]. Der Mann ohne Eigenschaften. (El hombre sin atributos). Reinbek bei Hamburg: Rowohlt.

Navascués, Javier de. 1992a. Adán Buenosayres. Una novela total. Pamplona: Eunsa.

- - - 1992b. "Entre el clasicismo y la vanguardia: la poesía de Leopoldo Marechal". En: Estudios en honor de Luka Brajnovic. Pamplona: Eunsa. 241-252.

- - -. 1997. "Sobre novela argentina: Rayuela y Adán Buenosayres". En: Leopoldo Marechal. Adán Buenosayres. Ed. Jorge Lafforgue y Fernando Colla. Paris: ALLCA XX/Ediciones Unesco (Colección "Archivos"). 957-966.

- -. 2017. Alpargatas contra libros. El escritor y las masas en la literatura del primer peronismo (1945-1955). Madrid-Frankfurt/M.: Iberoamericana-Vervuert.

Ortega, Julio. 1998. El principio radical de lo nuevo. Postmodernidad, identidad y novela en América Latina. México: Fondo de Cultura Económica.

Paz, Octavio. 1975. “Traducción y metáfora”. En: El Modernismo. Ed. Lily Litvak. Madrid: Taurus. 97-117.

Prieto, Julio. 2016. "Una gramática del desarraigo: visiones urbanas y técnicas de salvación en Roberto Arlt". En: Julio Prieto. La escritura errante. Ilegibilidad y politicas del estilo en Latinoamérica. Madrid-Frankfurt/M.: Iberoamericana-Vervuert. 47-87.

Rama, Ángel. 1970. Rubén Darío y el modernismo (Circunstancia socio-económica de un arte americano). Caracas: Ediciones de la Biblioteca de la Universidad Central de Venezuela.

- -. 1982. Transculturación narrativa en América Latina. México: Siglo XXI.

Ramos, Julio. 1989. Desencuentros de la modernidad en América Latina. Literatura y politica en el siglo XIX. México: Fondo de Cultura Económica.

Ramos, Marcos. 1979. Leopoldo Marechal como novelista cristiano. Buenos Aires: Círculo. Rancière, Jacques. 2000. Le Partage du sensible: Esthétique et politique. Paris: La Fabrique.

Rocco-Cuzzi, Renata. 2004. "Las epopeyas de Leopoldo Marechal". En: El oficio se afirma. Ed. Sylvia Saítta. Vol. IX (de Historia crítica de la literatura argentina, ed. Noé Jitrik). Buenos Aires: Emecé. 461-482.

Rodríguez Monegal, Emir. 1972. "Borges y Nouvelle Critique”. Revista Iberoamericana 80. 367-390. 
Rössner, Michael. 1988. Auf der Suche nach dem verlorenen Paradies. Zum mythischen Bewusstsein in der Literatur des 20. Jahrhunderts. Frankfurt/M.: Athenäum.

Romano, Eduardo. 1997. "La poesía de Leopoldo Marechal y lo poético en Adán Buenosayres". En: Leopoldo Marechal. Adán Buenosayres. Ed. Jorge Lafforgue y Fernando Colla. Paris: ALLCA XX/Ediciones Unesco (Colección "Archivos"). 618-653.

Saítta, Sylvia. 2000. El escritor en el bosque de ladrillos. Una biografía de Roberto Arlt. Buenos Aires: Sudamericana.

- - -. 2004. "Ciudades revisitadas". Revista de Literaturas Modernas 34. 135-149.

Sarlo, Beatriz. 1988. Una modernidad periférica: Buenos Aires 1920 y 1930. Buenos Aires: Nueva Visión.

- - - 1995. Borges, un escritor en las orillas. Buenos Aires: Ariel.

Viñas, David. 1971. "Cotidianeidad, clasicismo y tercera posición: Marechal”. En: David Viñas. Literatura argentina y realidad politica. De Sarmiento a Cortázar. Buenos Aires: Siglo Veinte. 103-109.

Virilio, Paul. 1980. Esthétique de la disparition. Paris: Balland.

Yurkievich, Saúl. 1983. "Borges: del anacronismo al simulacro". Revista Iberoamericana. 125. 693-704.

- - - 1984. Fundadores de la nueva poesía latinoamericana. Barcelona: Ariel.

- - -. 1996. "Las estratagemas narrativas de Borges". En: Saúl Yurkievich. La movediza modernidad. Madrid: Taurus. 193-207.

Zonana, Víctor Gustavo. 1991. "Breves notas sobre la metáfora vanguardista en Días como flechas de Leopoldo Marechal". Revista de Literaturas Modernas 24. 271-280.

Zubieta, Ana María. 1995. Humor, nación y diferencias. Arturo Cancela y Leopoldo Marechal. Rosario: Beatriz Viterbo. 
